\title{
International litigation and the dissaggregation of disputes: Ukraine/Russia as a case study
}

Article

Accepted Version

Hill-Cawthorne, L. (2019) International litigation and the dissaggregation of disputes: Ukraine/Russia as a case study. International \& Comparative Law Quarterly, 68 (4). pp. 779815. ISSN 0020-5893 doi:

https://doi.org/10.1017/S0020589319000411 Available at https://centaur.reading.ac.uk/85840/

It is advisable to refer to the publisher's version if you intend to cite from the work. See Guidance on citing.

To link to this article DOI: http://dx.doi.org/10.1017/S0020589319000411

Publisher: Cambridge University Press

All outputs in CentAUR are protected by Intellectual Property Rights law, including copyright law. Copyright and IPR is retained by the creators or other copyright holders. Terms and conditions for use of this material are defined in the End User Agreement.

www.reading.ac.uk/centaur 
Central Archive at the University of Reading

Reading's research outputs online 


\title{
INTERNATIONAL LITIGATION AND THE DISAGGREGATION OF DiSPUTES: UKRAINE/RUSSIA AS A CASE STUDY
}

\author{
Lawrence Hill-Cawthorne*
}

\begin{abstract}
This article explores the phenomenon of 'disaggregation' of disputes in international law, that is, the carving up of broader disputes into discrete legal claims based on different international legal rules and subject to the jurisdiction of different international tribunals. In particular, its focus is on certain under-explored consequences of this phenomenon for the jurisdiction of international tribunals, asking whether the relationship between the specific claims and the broader dispute might affect the jurisdiction of the tribunals. Employing the ongoing Ukraine/Russia dispute, which has yielded multiple claims before different international tribunals, the article offers an original analysis of these jurisdictional questions. It presents three approaches discernible from case law where tribunals face claims over which they appear to have jurisdiction that implicate a broader dispute over which they do not. The article ends with a consideration of possible explanations for why a tribunal might follow one approach over the others in any given case.
\end{abstract}

Keywords: jurisdiction; international litigation; procedure; Ukraine; Russia; incidental determinations

\section{INTRODUCTION}

It is well known that international law lacks an integrated system of international courts with general, compulsory jurisdiction. Instead, the structure of the international judiciary is decentralised, comprising multiple international courts and tribunals with differentiated jurisdictions. The consequence is often a disaggregation, or 'compartmentalization', of broader disputes into discrete legal claims before a range of international tribunals, each with jurisdiction to examine only those discrete claims. ${ }^{1}$ Sir Christopher Greenwood points to this disaggregation of disputes (in the context of compromissory clauses before the International Court of Justice) as a challenge frequently faced in international litigation:

... []f jurisdiction can be based only upon a clause of this kind, the consequence may be that the Court has jurisdiction only in respect of one aspect of what may be a far broader dispute between the states concerned ... One of the challenges for counsel in a case where the only basis for jurisdiction is a treaty dealing with a specific subject is to frame the case in such a way as to bring it within that treaty. An even greater challenge for the Court is to deal effectively with the case before it while remaining

\footnotetext{
* Associate Professor in Public International Law, University of Reading; 1.hill-cawthorne@reading.ac.uk. I am very grateful to the editors and the anonymous reviewers for their very constructive feedback. An earlier version of this article was presented at the Faculty of Law, University of Oslo in September 2018; I am very grateful for comments received there.

1 The language of 'compartmentalization' is borrowed from E Cannizzaro and B Bonafé, 'Fragmenting International Law through Compromissory Clauses? Some Remarks of the Decision of the ICJ in the Oil Platforms case' (2005) 16 EJIL 481, 484. Similarly, see CJ Tams, 'The Continued Relevance of Compromissory Clauses as a Source of ICJ Jurisdiction' in T Giegerich (ed), A Wiser Century? Judicial Dispute Settlement, Disarmament, and the Laws of Wars 100 Years After the Second Hague Peace Conference (Duncker \& Humblot, Berlin 2009) (‘... a jurisdiction that is treaty-specific thus favours the artificial truncation of disputes'); A Boyle, 'Dispute Settlement and the Law of the Sea Convention: Problems of Fragmentation and Jurisdiction' (1997) 46 ICLQ 37 (using the metaphor of 'salami-slicing'); A Zimmerman, 'Between the Quest for Universality and its Limited Jurisdiction: The Role of the International Court of Justice in Enhancing the International Rule of Law' in G Gaya and J Groute Stoutenburg (eds), Enhancing the Rule of Law Through the International Court of Justice (Brill, Leiden 2014) 40-1 (compromissory clauses 'might force the applicant State to squeeze the facts through the eye of a needle, and thereby to frame its application with a focus on one particular treaty only.').
} 
faithful to the proper interpretation of the clause which confers jurisdiction and to the fundamental principle of consent as the basis for jurisdiction. ${ }^{2}$

The range of tribunals before which claims have been brought concerning the ongoing dispute between Ukraine and the Russian Federation exemplifies this phenomenon of disaggregation. For the purposes of this article, this broad dispute refers to two particular issues arising subsequent to the ousting of Ukrainian President Viktor Yanukovych in February 2014. ${ }^{3}$ The first relates to Crimea and its annexation by Russia following the latter's swift occupation of the peninsula and convening of a referendum there in March 2014, in which a reported 97\% voted in favour of joining the Russian Federation. ${ }^{4}$ Ukraine continues to assert its claim to sovereignty over Crimea. ${ }^{5}$ The second issue relates to alleged Russian support for separatist movements in eastern Ukraine since 2014, including in the regions of Donetsk and Luhansk. ${ }^{6}$

This broad dispute has been disaggregated into a number of discrete legal claims before different international tribunals. ${ }^{7}$ At the inter-state level, Ukraine has brought proceedings against Russia before the International Court of Justice (ICJ), the European Court of Human Rights (ECtHR), and two tribunals constituted under Annex VII of the UN Convention on the Law of the Sea (UNCLOS). ${ }^{8}$ Five disputes between Ukraine and Russia have also made their way to the WTO dispute settlement system. With respect to mixed claims (where the parties are a mix of state and non-state actors), 4,300 individual claims are currently pending before the ECtHR that all appear related to the Ukraine/Russia dispute, and nine known investor-state arbitrations have been initiated by Ukrainian investors in Crimea against Russia. Finally, whereas the above claims all concern the invocation of state responsibility, the Ukraine/Russia dispute has also led to considerations of individual responsibility under international law. Thus, there is an ongoing preliminary examination into the situation in Crimea and eastern Ukraine by the Office of the Prosecutor of the International Criminal Court (ICC).

This article explores this phenomenon of the disaggregation of disputes in international law, employing the Ukraine/Russia dispute as a case study. ${ }^{9}$ The topic is, to an extent, related to the issue of the multiplication of international courts and tribunals, which has been explored in detail elsewhere. ${ }^{10}$ It is not the purpose of the present contribution to rehearse what is already covered

${ }^{2}$ CJ Greenwood, 'Some Challenges of International Litigation' (2012) 1 Cambridge J Intl \& Comp L 7, 16.

3 W Booth, 'Ukraine's Parliament Votes to Oust President; Former Prime Minister is Freed From Prison', The Washington Post, 22 February 2014; S Walker, 'Ousted Ukrainian Leader Viktor Yanukovych Reported to be in Russia', The Guardian, 27 February 2014.

${ }^{4}$ SL Myers and E Barry, 'Putin Reclaims Crimea for Russia and Bitterly Denounces the West', The New York. Times, 18 March 2014.

${ }^{5}$ President of Ukraine, 'President: After Restoration of its Sovereignty in Crimea, Ukraine Will Use the Kerch Strait Bridge for Ties with the Kuban’, 18 May 2018, available at https://www.president.gov.ua/en/news/ukrayina-pislyavidnovlennya-svogo-suverenitetu-v-krimu-viko-47522.

6 'Ukraine Says Donetsk “Anti-Terror Operation” Under Way', BBC News, 16 April 2014; DM Herszenhorn and P Baker, 'Russia Steps Up Help for Rebels in Ukraine War', The New York Times, 25 July 2014; A Luhn and D Roberts, 'Ukraine Condemns "Direct Invasion" as Russian Aid Convoy Crosses Border', The Guardian, 23 August 2014; 'Ukraine Separatists Declare Independence', Al-Jazeera, 12 May 2014; J Coman, 'On the Frontline of Europe’s Forgotten War in Ukraine', The Guardian, 12 November 2017.

7 The claims referred to here are cited in full when discussed later in the article.

${ }^{8}$ United Nations Convention on the Law of the Sea (adopted 10 December 1982, entered into force 16 November 1994), 1833 UNTS 3.

9 'The term 'disaggregation' is used here over other frequently used descriptions of this phenomenon, such as 'framing' of disputes or 'compartmentalization'. It is considered that 'disaggregation' better captures the fact, particularly featured in the Ukraine/Russia litigation, that each claim is often not merely a different way of framing the broader dispute but a specific legal claim arising from that broader dispute and existing in parallel with other specific legal claims. It also reminds us that this phenomenon is not merely a litigation strategy but also a structural feature of international judicial settlement.

${ }^{10}$ For a very small selection, see, eg, 'Address by HE Judge Gilbert Guillaume, President of the International Court of Justice, to the United Nations General Assembly', 26 October 2000, available at https://www.icjcij.org/files/press-releases/9/2999.pdf; JI Charney, 'Is International Law Threatened by Multiple International 
there. Instead, the aim of this article is to use this case study to examine certain under-explored consequences of the disaggregation of disputes for the jurisdiction of tribunals. More specifically, it focuses on two questions. First, what is the relationship between the specific claims before each of the tribunals in these cases and other aspects of the broader Ukraine/Russia dispute? Second, what impact might the disaggregation of the dispute have on the jurisdiction of the tribunals? In particular, might the relationship between the specific claims before each tribunal and the broader dispute affect the jurisdiction of the tribunals over those specific claims? This is particularly pertinent, given Russia's jurisdictional objections before some of the tribunals that Ukraine's specific claims are inseparable from the broader dispute over which the tribunal lacks jurisdiction, with the consequence that the tribunal cannot exercise jurisdiction over any part of the claims. ${ }^{11}$

Some recent scholarship examines some of the legal claims arising from the Ukraine/Russia dispute, as well as some of the jurisdictional issues addressed in this article. ${ }^{12}$ However, the present article advances the current literature in at least two ways. First, it is more comprehensive than the previous literature on the Ukraine/Russia dispute in terms of the range of tribunals and types of claims examined. Second, and most importantly, it also goes beyond that previous literature in its treatment of the jurisdictional issues explored. In particular, this article offers an original analysis of the approach of different tribunals to the jurisdictional issues considered here, suggesting three distinct approaches to disaggregation across jurisprudence: first, the severability approach, by which a tribunal stresses the severability of the specific claims before it from any broader dispute; second, the restrictive approach, by which a tribunal views the claims before it as inseparable from that broader dispute and, as a result, declines jurisdiction even over those specific claims; and, third, the expansive approach, by which the tribunal does not attempt to sever the claims before it from the broader dispute and, instead, willingly makes incidental determinations that would otherwise be beyond its jurisdiction when ruling on the specific claims. In the final section, the article also draws these doctrinal questions of jurisdiction back to broader considerations about the role of particular tribunals and the international judicial function more generally. Though the Ukraine/Russia dispute is used a case study, it will become clear that these issues arise frequently in international litigation, and thus the present contribution offers an analysis of relevance generally to international dispute settlement.

The article is structured as follows. Section two introduces in turn the claims before each tribunal and their potential implications for the broader Ukraine/Russia dispute. Section three then elaborates on the three approaches to disaggregation and the jurisdictional questions raised above that one can draw out of the jurisprudence of different international courts and tribunals. Section four then offers an explanation of the different approaches to these issues and, in particular,

Tribunals?' (1998) 271 RdC 1; B Kingsbury, 'Foreword: Is the Proliferation of International Courts and Tribunals a Systemic Problem?' (1999) 31 AJIL 679; P-M Dupuy, 'The Danger of Fragmentation or Unification of the International Legal System and the International Court of Justice' (1999) 31 AJIL 791; G Abi-Saab, 'Fragmentation or Unification? Some Concluding Remarks' (1999) 31 AJIL 919; K Oellers-Frahm, 'Multiplication of International Courts and Tribunals and Conflicting Jurisdiction - Problems and Possible Solutions' (2001) 5 Max Planck YB UN L 67; J Pauwelyn and EL Salles, 'Forum Shopping before International Tribunals: (Real) Concerns, (Im)Possible Solutions' (2009) 42 Cornell Intl LJ 77; P Webb, International Judicial Integration and Fragmentation (OUP, Oxford 2016); A Pellet, 'Should We (Still) Worry About Fragmentation?' in A Føllesdal and G Ulfstein (eds), The Judicialization of International Law: A Mixed Blessing? (OUP, Oxford 2018); L Boisson de Chazournes, 'Plurality in the Fabric of International Courts and Tribunals: The Threads of a Managerial Approach' (2017) 28 EJIL 13.

11 As discussed below, Russia has invoked this preliminary objection before both the ICJ and Annex VII tribunals: see below at text to nn 89-92 and text to nn 120-21, respectively.

12 TD Grant, 'International Dispute Settlement in Response to an Unlawful Seizure of Territory: Three Mechanisms' (2015) 16 Chicago J Intl L 1; OG Repousis, 'Why Russian Investment Treaties Could Apply to Crimea and What Would This Mean for the Ongoing Russo-Ukrainian Territorial Conflict' (2016) 32 Arb Intl 459; RG Volterra, GF Mandelli, and Á Nistal, 'The Characterization of the Dispute Concerning Coastal State Rights in the Black Sea, Sea of Arov, and Kerch Strait' (2018) 33 Intl J Maritime \& Coastal L 614; P Tzeng, 'The Implicated Issue Problem: Indispensable Issues and Incidental Jurisdiction' (2018) 50 NYU J Intl L \& Pol 447; G Nuridzhanian, 'Crimea in International Courts and Tribunals: Matters of Jurisdiction' (2018) 21 Max Planck YB UN Law 378. 
considers whether the nature of a particular tribunal might go some way in explaining its approach to these questions. Some concluding remarks will be offered in section five.

\section{THE UKRAINE/RUSSIA CLAIMS AND THEIR POTENTIAL IMPLICATIONS FOR THE BROADER DISPUTE}

The purpose of this section is briefly to introduce the principal claims in the Ukraine/Russia dispute. The claims before each tribunal are set out in turn, together with a brief consideration of their implications for the broader inter-state dispute.

\section{A. International Court of Justice}

In January 2017, Ukraine instituted proceedings before the ICJ against Russia. The claims concern alleged violations of the International Convention for the Suppression of the Financing of Terrorism (ICSFT) in eastern Ukraine and of the International Convention on the Elimination of All Forms of Racial Discrimination (CERD) in Crimea. ${ }^{13}$

It is, of course, the compromissory clauses in the ICSFT and CERD that explains Ukraine's invocation of these treaties. ${ }^{14}$ In its application, Ukraine points in passing to a range of other alleged violations by Russia, including violations of the principle of non-intervention, the prohibitions on the use of force and conquest, and the right to life of Ukrainian nationals. ${ }^{15}$ However, in the absence of optional clause declarations from either state, compromissory clauses in relevant treaties, such as the UN Charter or the International Covenant on Civil and Political Rights, ${ }^{16}$ or a special agreement between the parties, there exists no explicit basis for the Court to exercise jurisdiction over claims relating to these other aspects of the broader dispute. The ICSFT and CERD offer the only door through which the Court might examine certain aspects of Ukraine's allegations.

This brings us to the question of the possible ways in which that broader dispute might nonetheless be implicated in the Court's assessment of the specific legal claims before it. Regarding the CERD claims, none of those claims clearly implicates the occupation and annexation of Crimea, as the majority of the provisions in CERD are not territorially limited. Nonetheless, at various points in its memorial, Ukraine does allude to Russia's annexation of Crimea in the context of its CERD claims. For example, Ukraine submits that interpreting certain provisions of CERD requires a renvoi to Article 49 of the Fourth Geneva Convention, which only applies in occupied territory. ${ }^{17}$ Furthermore, Ukraine argues that Russia cannot invoke those clauses in CERD providing for certain non-precluded measures as that would be tantamount to allowing Russia to

\footnotetext{
${ }^{13}$ International Convention for the Suppression of the Financing of Terrorism (adopted 9 December 1999, entered into force 10 April 2002), 2178 UNTS 197 (hereinafter 'ICSFT'); International Convention on the Elimination of All Forms of Racial Discrimination (adopted 7 March 1966, entered into force 4 January 1969), 660 UNTS 195 (hereinafter 'CERD').

14 Art 24(1) ICSFT; Art 22 CERD.

15 See, eg, Application of the International Convention for the Suppression of the Financing of Terrorism and of the International Convention on the Elimination of All Forms of Racial Discrimination (Ukraine v Russia), Application Instituting Proceedings, 16 January 2017, [1]-[4].

${ }_{16}$ Charter of the United Nations (adopted 26 June 1945, entered into force 24 October 1945), 1 UNTS XVI; International Covenant on Civil and Political Rights (adopted 16 December 1966, entered into force 23 March 1976), 999 UNTS 171.

${ }^{17}$ Case Concerning Application of the International Convention for the Suppression of the Financing of Terrorism and of the International Convention on the Elimination of All Forms of Racial Discrimination (Ukraine v Russian Federation), Memorial (Submitted by Ukraine), 12 June 2018, [614].
} 
invoke its own unlawful conduct (its annexation of Crimea) to justify its actions. ${ }^{18}$ How the Court will engage with these submissions remains to be seen.

Regarding the ICSFT, the position may be more complicated. Throughout the proceedings thus far, Ukraine alleges as part of its ICSFT claims, inter alia, that Russia directly finances separatist groups in eastern Ukraine that carry out terrorist attacks. ${ }^{19}$ Russia has responded that the focus of the ICSFT is on states parties cooperating to suppress the financing of such actions by private actors, as opposed to the financing of such acts by states themselves. ${ }^{20}$ Part of Ukraine's reasoning here relies on an analogy to the Court's approach to a similar question in Bosnia v Serbia, ${ }^{21}$ which, if accepted, might enable the Court to consider claims of direct Russian support for separatists as part of the ICSFT claims. ${ }^{22}$ Should the Court take up this invitation, the scope for the ICJ to draw on the broader dispute between Ukraine and Russia would be enlarged.

\section{B. Annex VII UNCLOS tribunal}

Under the auspices of the Permanent Court of Arbitration (PCA), Ukraine instituted inter-state arbitral proceedings in September 2016 against Russia under Annex VII of UNCLOS, alleging various violations by Russia of Ukraine's rights under the Convention. ${ }^{23}$ In addition, Ukraine has instituted further Annex VII proceedings in relation to Russia's seizure and detention of Ukrainian warships and their crews in the Kerch Strait in November 2018; pending constitution of that Tribunal, Ukraine requested the indication of provisional measures by the International Tribunal for the Law of the Sea (ITLOS). ${ }^{24}$

It is particularly with respect to the 2016 UNCLOS claims that the broader territorial dispute concerning Crimea may be implicated, and even more so than in the ICJ proceedings. ${ }^{25}$ This is because they involve claims that Russia has violated Ukraine's rights as the coastal state under UNCLOS in the Black Sea, Sea of Azov and Kerch Strait. ${ }^{26}$ Given the law of the sea principle that sovereignty over maritime areas is determined by sovereignty over adjacent land (the so-called 'land dominates the sea' principle), this requires a determination of which state is the territorial

\footnotetext{
18 Ibid, [613], [625]-[626].

19 Ibid, [296]-[318]; Application of the International Convention for the Suppression of the Financing of Terrorism and of the International Convention on the Elimination of All Forms of Racial Discrimination (Ukraine $v$ Russian Federation), Order (Provisional Measures), 19 April 2017, [66], [68].

${ }^{20}$ Case Concerning Application of the International Convention for the Suppression of the Financing of Terrorism and of the International Convention on the Elimination of All Forms of Racial Discrimination (Ukraine v Russian Federation), Preliminary Objections (Submitted by the Russian Federation): Vol I, [126]-[227].

21 Application of the Convention on the Prevention and Punishment of the Crime of Genocide (Bosnia and Herzeogovina $v$ Serbia and Montenegro) (Merits Judgment) [2007] ICJ Rep 43, [166] ('[i]t would be paradoxical if States were under an obligation to prevent, so far as within their power, commission of genocide by persons over whom they have a certain influence, but were not forbidden to commit such acts through their own organs ... In short, the obligation to prevent genocide necessarily implies the prohibition of the commission of genocide').

${ }^{22}$ For an articulation of the opposing views on this, see Memorial (Ukraine) (n 17) [306]-[307]; Preliminary Objections (Russia) (n 20) [199]-[209].

${ }^{23}$ Dispute Concerning Coastal State Rights in the Black Sea, Sea of Azov, and Kerch Strait (Ukraine v Russian Federation), PCA Case No 2017-06, Proceedings Commenced 16 September 2016.

${ }^{24}$ Case Concerning the Detention of Three Ukrainian Naval Vessels (Ukraine v Russian Federation), Case No 26 (ITLOS), Request for the Prescription of Provisional Measures (Order), 25 May 2019.

25 In the case of the November 2018 UNCLOS proceedings, Ukraine emphasises that its claims are agnostic as to where sovereignty over Crimea lies: Case Concerning the Detention of Three Ukrainian Vessels (Ukraine v Russian Federation), ITLOS/PV.19/C26/1, Verbatim Record, 10 May 2019, 13. Though note Russia's disagreement on this point: Case Concerning the Detention of Three Ukrainian Naval Vessels (Ukraine v The Russian Federation), Case No 26 (ITLOS), Provisional Measures (Memorandum of the Government of the Russian Federation), 7 May 2019, 15 (fn 58).

${ }^{26}$ For a list of Ukraine's claims in this case, see In the Matter of a Dispute Concerning Coastal State Rights in the Black Sea, Sea of Azov, and Kerch Strait (Ukraine v The Russian Federation), PCA Case No 2017-06, Written Observations and Submissions of Ukraine on Jurisdiction, 27 November 2018, [23].
} 
sovereign in Crimea ${ }^{27}$ Indeed, in contrast to its pleadings thus far in the UNCLOS dispute relating to the November 2018 Kerch Straight incident, ${ }^{28}$ Ukraine does not dispute that its 2016 claims are premised on its sovereignty over Crimea. ${ }^{29}$ These particular UNCLOS claims thus seem to implicate the sovereignty dispute over Crimea.

\section{European Court of Human Rights}

The claims before the ECtHR comprise both inter-state and mixed claims. At the time of writing, there are five pending inter-state applications to the ECtHR brought by Ukraine against Russia relating to the dispute under consideration here. ${ }^{30}$ These include two consolidated cases, pending before the Grand Chamber at the time of writing, one of which relates to claims concerning Crimea and the other to claims concerning eastern Ukraine. ${ }^{31}$ In these cases, Ukraine alleges Russian responsibility for violations of a range of rights protected under the European Convention on Human Rights (ECHR) in Crimea and eastern Ukraine, ${ }^{32}$ arguing that Russia exercises jurisdiction by virtue of its effective control over Crimea and its control of separatists and armed groups in eastern Ukraine. ${ }^{33}$ The third case concerns the alleged abduction of three groups of children in eastern Ukraine by separatist forces and their temporary transfer to Russia. ${ }^{34}$ The fourth is an August 2018 application lodged by Ukraine that concerns the detention and prosecution of Ukrainian nationals by Russia. ${ }^{35}$ The fifth case relates to the November 2018 incident in the Kerch Strait. ${ }^{36}$

In addition to the inter-state applications, at the time of writing there are also approximately 4,300 individual applications before the ECtHR, against both Russia and Ukraine, that all appear related to the events in Crimea or eastern Ukraine. ${ }^{37}$ Amongst the pending cases are claims against Ukraine by relatives of the victims of the MH17 disaster who allege that Ukraine failed to protect those victims' lives by not closing their airspace over the armed conflict in the region (thus violating their positive obligations).$^{38}$ Russia's responsibility for the destruction of $\mathrm{MH} 17$ is similarly invoked in some of these individual applications, both in the form of directly attributing the attack to Russia and as an alleged violation of Russia's positive obligations. ${ }^{39}$

\footnotetext{
27 See, eg, North Sea Continental Shelf (Federal Republic of Germany/Denmark; Federal Republic of Germany/Netherlands), Judgment (Merits) [1969] ICJ Rep 3, [96]; Aegean Sea Continental Shelf (Greece v Turkey) [1978] ICJ Rep 3, [186].

${ }^{28}$ See above at $\mathrm{n} 25$.

${ }^{29}$ In the Matter of a Dispute Concerning Coastal State Rights in the Black Sea, Sea of Azov, and Kerch Strait (Ukraine v The Russian Federation), PCA Case No 2017-06, Rejoinder of Ukraine on Jurisdiction, 28 March 2019, [10]-[11] (arguing instead that Russia has no plausible claim to Crimea and thus that there is no true dispute over its status).

30 See ECtHR Press Release, 'ECHR to adjourn some individual applications on Eastern Ukraine pending Grand Chamber judgment in related inter-State case', ECHR 432 (2018), 17 December 2018.

${ }^{31}$ Ukraine v Russia (re Crimea), App No 20958/14; Ukraine v Russia (re Eastern Ukraine), App No 8019/16.

${ }^{32}$ Convention for the Protection of Human Rights and Fundamental Freedoms (adopted 4 November 1950, entered into force 3 September 1953), 213 UNTS 221.

${ }^{33}$ ECtHR Press Release, 'European Court of Human Rights deals with cases concerning Crimea and Eastern Ukraine', ECHR 345 (2014), 26 November 2014; ECtHR Press Release, 'European Court of Human Rights communicates to Russia to inter-State case concerning events in Crimea and Eastern Ukraine', ECHR 296 (2015), 1 October 2015.

${ }^{34}$ Ukraine v Russia (II), App No 43800/14; see ECtHR Press Release, 'European Court of Human Rights deals with cases concerning Crimea and Eastern Ukraine', ECHR 345 (2014), 26 November 2014.

35 Ukraine v Russia (VII), App No 38334/18; see ECtHR Press Release, 'New inter-State application brought by Ukraine against Russia', ECHR 277 (2018), 27 August 2018.

36 Ukraine v Russia (VIII), App No 55855/18; see ECtHR Press Release, 'ECHR puts questions to Russian Government after receiving new inter-State case from Ukraine concerning events in the Sea of Azov', ECHR 412 (2018), 30 November 2018.

37 ECtHR Press Unit, Armed Conflicts (May 2018) 17, available at https://www.echr.coe.int/Documents/FS Armed conflicts ENG.pdf.

38 Ioppa et al $v$ Ukraine, App Nos 73776/14, 974/15, 4407/15, 4412/15.

39 Ayley and others v Russia, Angline and others v Russia, App Nos 25714/16 and 56328/18.
} 
In certain respects, these ECHR claims are likely to implicate the broader inter-state dispute. It is clear that Russia's alleged intervention in eastern Ukraine will directly be raised in these cases, as the Court will need to consider whether Russia exercises Article 1 ECHR jurisdiction in the region, including, potentially, through the separatists operating there. ${ }^{40}$ Indeed, in its previous case law, the Court has held states responsible for the actions of separatists on another state's territory on the basis of the foreign state's control, though it has not been made clear whether that is a result of its control over territory (thus engaging the positive obligations of the state in areas within its jurisdiction) or control over the separatists themselves whose actions are then attributable to the state. ${ }^{41}$ In either case, however, assessing the ECHR claims would likely require a consideration of the degree of Russian intervention in eastern Ukraine and its support of separatists.

The relationship between the ECHR claims and the sovereignty dispute over Crimea is more complicated. On the one hand, the Court's extensive jurisprudence on extraterritoriality demonstrates its willingness to extend the Convention to territory over which states parties exercise effective control. ${ }^{42}$ This would suggest that there is no need to consider the sovereignty question in order to determine the applicability of the Convention to Russia's actions in Crimea. Nevertheless, questions of sovereignty have arisen in previous ECHR cases for the purposes of finding a (limited) residual jurisdiction of the sovereign state in parallel with (full) jurisdiction of the foreign state exercising effective control. ${ }^{43}$ Furthermore, the Court might also be drawn into the sovereignty question at the merits stage if it is called on to make a renvoi to IHL to interpret the Convention rights in the Crimea context. ${ }^{44}$ Thus, it may be faced with the question of the applicability of the law of occupation to Crimea, with the consequence that it would need to determine whether Russia is an occupying power or the sovereign in the peninsula. ${ }^{45}$

\section{WTO disputes ${ }^{46}$}

At the time of writing, two cases are pending before the WTO dispute settlement system between Russia and Ukraine, ${ }^{47}$ with panel reports having recently been issued in three further cases. ${ }^{48}$ Unlike the proceedings noted above, these do not concern claims arising directly from the dispute over Crimea or eastern Ukraine. Instead, they all concern the compatibility with WTO law of various

\footnotetext{
${ }^{40}$ ECtHR Press Release, 'ECHR to adjourn some individual applications on Eastern Ukraine pending Grand Chamber judgment in related inter-State case', ECHR 432 (2018), 17 December 2018 (recognising the need to determine which state has Article 1 jurisdiction in eastern Ukraine, and adjourning individual applications concerning the region until the jurisdictional issue is addressed in Ukraine v Russia (re Eastern Ukraine), App No 8019/16); Ayley and others v Russia, Angline and others $v$ Russia, App Nos 25714/16 and 56328/18, Communication dated 3 April 2019 (asking the parties on what basis Russia exercised jurisdiction in eastern Ukraine).

${ }^{41}$ Ilaşcu et al $v$ Moldova \& Russia, App No 48787/99, Judgment of 8 July 2004 (Grand Chamber); Catan v Moldova \& Russia, 43370/04, 8252/05, 18454/06, Judgment of 19 October 2012 (Grand Chamber); Sandu and others v Moldova and Russia, App No 21034/05 and others, Judgment of 17 July 2018; M Milanović \& T Papić, 'The Applicability of the ECHR in Contested Territories' (2018) 67 ICLQ 779, 789.

${ }^{42}$ The leading case on this remains Al-Skeini et al v United Kingdom, App No 55721/07, Judgment of 7 July 2011 (Grand Chamber).

${ }^{43}$ Ilasscu (n 41) [330]-[331]; Catan (n 41) [109]-[110]; Sandu (n 41) [34]-[35]. For critiques of the concept of residual jurisdiction, see Milanović and Papić (n 41); L Raible, 'Title to Territory and Jurisdiction in International Human Rights Law: Three Models for a Fraught Relationship' (2018) 31 Leiden J Intl L 315.

${ }^{44}$ The Strasbourg Court has explicitly employed IHL to interpret the Convention in the context of an international armed conflict in Hassan v United Kingdom, App No 29750/09, Judgment of 10 September 2014 (Grand Chamber).

45 The Court in Hassan v United Kingdom held that it would only consider such questions of IHL if specifically pleaded: ibid, [107].

${ }^{46}$ I am very grateful to Nicolas Lamp for discussions that have informed this section.

47 Ukraine - Measures Relating to Trade in Goods and Services (Russia), DS525; Russia - Measures Concerning the Importation and Transit of Certain Ukrainian Products (Ukraine), DS532.

${ }^{48}$ Russia - Measures Concerning Traffic in Transit (Ukraine) [2019] WT/DS512/R (Panel Report); Ukraine - Anti-Dumping Measures on Ammonium Nitrate (Russia) [2018] WT/DS493/R (Panel Report); Russia - Measures Affecting the Importation of Railway Equipment and Parts Thereof (Ukraine) [2018] WT/DS499/R (Panel Report).
} 
trade-related measures introduced by each state. In this sense, one could view them as entirely separate from the broader inter-state dispute that is the focus of this article.

However, the WTO cases are included here given the potential for aspects of the broader dispute between Ukraine and Russia to arise in these proceedings. For example, in the recently adopted panel report in Russia - Traffic in Transit, Ukraine challenged a number of Russian restrictions on Ukrainian traffic in transit through Russia to third states. In defence, Russia successfully invoked Article XXI(b)(iii) of the General Agreement on Tariffs and Trade (GATT) to justify its measures, ${ }^{49}$ and the panel was thus the first WTO panel called on to address the longstanding debate over the justiciability of that provision. ${ }^{50}$ Russia's invocation of Article XXI(b)(iii), in permitting action considered necessary by the state for its essential security interests 'taken in time of war or other emergency in international relations', could have implicated aspects of the broader dispute between Ukraine and Russia. This would be the case, for example, had Ukraine claimed that Russia's reliance on Article XXI(b)(iii) represented an abuse of right on the basis of the latter's alleged intervention in eastern Ukraine and its occupation of Crimea. Simply put, Russia's reliance on a situation to which it allegedly has contributed so as to justify deviation from its obligations could, on this argument, be viewed as a bad faith invocation by Russia of Article XXI(b)(iii). ${ }^{51}$ Though Ukraine has raised a similar argument in the ICJ proceedings with respect to certain non-precluded measures under CERD, ${ }^{52}$ as well as in the UNCLOS proceedings in response to Russia's preliminary objections, ${ }^{53}$ there is no indication that it made such an argument before the WTO panel. ${ }^{54}$ The Dispute Settlement Body subsequently adopted the panel report, but whether similar arguments might arise in other cases remains to be seen.

\section{E. Investment arbitrations}

\footnotetext{
${ }^{49}$ Russia - Traffic in Transit (n 48), [7.27]-[7.149].

50 The panel rejected the self-judging view of Article XXI GATT: ibid. See the different views on this in the third party submissions: Russia - Measures Concerning Traffic in Transit (DS512), European Union Third Party Written Submission, 8 November 2017; Russia - Measures Concerning Traffic in Transit (DS512), Third Party Oral Statement of the United States, 25 January 2018. More generally, see RP Alford, ‘The Self-Judging WTO Security Exception’ [2011] Utah L Rev 697; JY Yoo and D Ahn, 'Security Exceptions in the W'TO System: Bridge or Bottle-Neck for Trade and Security?' (2016) 19 JIEL 417; D Akande and S Williams, 'International Adjudication on National Security Issues: What Role for the WTO?' (2003) 43 Va J Intl L 365.

${ }^{51}$ The panel in Russia - Traffic in Transit ( $\left.\mathrm{n} 48\right)$ at [7.132] held the chapeau of Article XXI(b) to be subject to the principle of good faith. The WTO Appellate Body has previously held that the principle of good faith and the doctrine of abus de droit are embodied in the chapeau of Article XX GATT: United States - Import Probibition of Certain Shrimp and Shrimp Products (United States), WT/DS58/AB/R, 12 October 1998, [158].

52 Memorial (Ukraine) (n 17) [613], [625]-[626].

53 Dispute Concerning Coastal State Rights in the Black Sea, Sea of Azov, and Kerch Strait, Written Observations and Submissions of Ukraine on Jurisdiction (n 26) [32]; Dispute Concerning Coastal State Rights in the Black Sea, Sea of Azov, and Kerch Strait, Rejoinder of Ukraine on Jurisdiction (n 29) 13 (fn 56).

${ }^{54}$ Russia - Traffic in Transit (n 48) [7.121].
} 
A number of individual claims ${ }^{55}$ have also been brought by Ukrainian investors against Russia under the 1998 bilateral investment treaty (BIT) between the two states. ${ }^{56}$ These cases involve claims by Ukrainian investors of violations of the BIT by Russia in Crimea ${ }^{57}$ Russia has refused to engage with these claims on the basis that it does not recognise the jurisdiction of the tribunals. ${ }^{58}$

As mixed claims by individual investors against Russia, as opposed to claims by Ukraine, these are, of course, quite distinct from the inter-state claims discussed above and the broader inter-state dispute. Indeed, the dual-track nature of mixed and inter-state claims under BITs (including under the 1998 Russia-Ukraine BIT) ensures that private investors' claims in these mixed cases are legally distinct from any inter-state claims. ${ }^{59}$ However, it is clear that these investorstate arbitrations do implicate the inter-state dispute. First, Ukraine's interest in these cases is confirmed by its successful applications to make written submissions as a non-disputing party. ${ }^{60}$ Second, though the majority of the BIT claims are brought by wholly private Ukrainian investors, two of the known cases involve (Ukrainian) state-owned claimants. ${ }^{61}$ This indicates a closer link between at least some of these BIT claims and the broader inter-state dispute than the formal bifurcation of investor-state and inter-state proceedings under the BIT suggests.

Third, and most importantly for our purposes, these claims call for an application of Russia's obligations under the 1998 BIT to Crimea. The BIT covers investments by one of the state's nationals in the 'territory' of the other state. ${ }^{62}$ The success of these claims thus appears conditioned on the tribunals' recognition that Crimea now forms part of Russia's 'territory' for the purposes of the BIT (and that those that were previously domestic Ukrainian investors became foreign investors protected by the BIT following Russia's intervention in Crimea). Like the Annex VII tribunal addressing Ukraine's UNCLOS claims, and potentially the ECtHR regarding the ECHR claims, it would appear that these investment tribunals would need to make determinations regarding the territorial status of Crimea in order to rule on the merits of the claims. As explained below, however, in some recent decisions the tribunals have sought to avoid any such suggestion of a relationship between the BIT claims and the broader sovereignty dispute.

\footnotetext{
55 At the time of writing, nine cases have been registered with the PCA and/or reported: NJSC Naftogaz, of Ukraine (Ukraine) et al $v$ The Russian Federation, PCA Case No 2017-16, Proceedings Commenced 17 October 2016; Everest Estate LLC et al $v$ The Russian Federation, PCA Case No 2015-36, Proceedings Commenced 19 June 2015; PJSC Ukrnafta $v$ The Russian Federation, PCA Case No 2015-34, Proceedings Commenced 15 June 2015; Stabil LLC et al $v$ The Russian Federation, PCA Case No 2015-35, Proceedings Commenced 15 June 2015; Limited Liability Company Lugzor et al $v$ The Russian Federation, PCA Case No 2015-29, Proceedings Commenced 26 May 2015; PJSC CB PrivatBank and Finance Company Finilon LLC v The Russian Federation, PCA Case No 2015-21, Proceedings Commenced 13 April 2015; Aeroport Belbek LLC and Mr. Igor V aleriecich Kolomoisky v The Russian Federation, PCA Case No 2015-07, Proceedings Commenced 13 January 2015. The other two cases, Oschadbank v Russian Federation and DTEK Krymenergo v Russian Federation, are reported: see, respectively, Luke Eric Peterson, 'In the First of a Possible Wave of BIT Claims by Ukraine StateOwned Entities Against Russia, An UNCITRAL Tribunal is Finalized', IAReporter, 14 August 2016; 'Russian BIT Claims: Recent Developments in Arbitrations Against the Russian Federation', LAReporter, 13 April 2017.

56 Agreement between the Government of the Russian Federation and the Cabinet of Ministers of the Ukraine on the Encouragement and Mutual Protection of Investments (adopted 27 November 1998, entered into force 27 January 2000) 7 Bull Intl Treaties 18.

${ }^{57}$ See, eg, 'Ukraine's Naftogaz Files BIT Arbitration Against Russia', LAReporter, 19 October 2016; PCA Press Release, 'Arbitration between Everest Estate LLC and Others as Claimants and the Russian Federation', 9 August 2016; PCA Press Release, 'Arbitration between PJSC Ukrnafta as Claimant and the Russian Federation-Arbitration between Stabil LLC and Ten Others as Claimants and the Russian Federation', 2 May 2016; PCA Press Release, 'Arbitration Between Aeroport Belbek LLC and Mr. Igor Valerievich Kolomoisky as Claimants and the Russian Federation’, 6 January 2016. 58 See, eg, PCA Press Release, 6 January 2016 (n 57).

59 Art 9 of the 1998 BIT (on investor-state dispute settlement) and Art 10 of the 1998 BIT (on inter-state dispute settlement).

${ }^{60}$ See, eg, PCA Press Release, 'Arbitration between PJSC Ukrnafta as Claimant and The Russian Federation Arbitration between Stabil LC and Ten Others as Claimants and The Russian Federation', 4 August 2016; PCA Press Release, 'Arbitration between Everest Estate LLC and Others as Claimants and the Russian Federation', 13 January 2017.

61 'Ukraine's Naftogaz Files BIT Arbitration Against Russia' (n 57); Peterson (n 55).

${ }^{62}$ See especially Arts 1(1), 2(1), 4 and 5(1) of the 1998 BIT.
} 


\section{F. International criminal proceedings ${ }^{63}$}

A number of efforts have been made to hold individuals accountable for violations of international law committed in the course of the hostilities in Ukraine. Particularly prominent have been attempts to hold to account those responsible for the destruction of Malaysia Airlines Flight MH17. For example, an attempt to create an International Criminal Tribunal for Malaysia Airlines Flight MH17 through a draft Security Council resolution was vetoed by Russia in July 2015. ${ }^{64}$ Others have suggested alternative venues for invoking individual responsibility, particularly with respect to MH17, such as an adversarial model of a commission of inquiry, an international criminal tribunal established by the General Assembly, national criminal proceedings ${ }^{65}$ or a Lockerbie-style court. ${ }^{66}$

Against this background, the Office of the Prosecutor (OTP) of the ICC is examining allegations of international crimes committed in Ukraine. Though Ukraine is not a party to the Rome Statute, ${ }^{67}$ following the Euromaiden protests the new government lodged two declarations under Article 12(3) of the Rome Statute. The first, deposited on 17 April 2014, focused on crimes committed during the Euromaiden protests between 21 November 2013 and 22 February 2014. ${ }^{68}$ The second, dated 8 September 2015, extended this by granting the ICC jurisdiction 'for the purpose of identifying, prosecuting and judging the perpetrators and accomplices of acts committed in the territory of Ukraine since 20 February 2014'. ${ }^{69}$ This second declaration thus potentially brings events in eastern Ukraine and Crimea within the jurisdiction of the Court. The situation in Ukraine is currently under preliminary examination by the OTP to determine whether the cumulative requirements of jurisdiction, admissibility and the interests of justice are met in order to open an investigation. ${ }^{70}$ With respect to Crimea and eastern Ukraine, the Prosecutor has collected information on crimes within the Court's jurisdiction allegedly committed in those regions. ${ }^{71}$

Notwithstanding the nature of these proceedings as ones concerning individual criminal responsibility, there is a clear relationship between them and the broader inter-state dispute. First, and most fundamentally, there is a need to consider whether Crimea is a part of Ukraine's 'territory', at least for the purposes of the Rome Statute, as the Court's jurisdiction over events there is conditional on such a finding. ${ }^{72}$

Second, the relationship between the specific investigations before the ICC and the broader inter-state dispute also arises with respect to the applicable law. In particular, there is a need to consider the character of any armed conflict that may exist in Crimea or eastern Ukraine, in order

\footnotetext{
${ }^{63}$ I am very grateful to Rogier Bartels for discussions that have informed this section.

${ }^{64}$ UN Security Council Draft Resolution, S/2015/562, 29 July 2015. For details of the vote, see UN Security Council Press Release, 'Security Council Fails to Adopt Resolution on Tribunal for Malaysia Airlines Crash in Ukraine, Amid Calls for Accountability, Justice for Victims', SC/11990, 29 July 2015.

${ }^{65}$ Criminal investigations in the Netherlands have led to charges being brought against four individuals (three of whom are Russian nationals), with trials reportedly due to the start there (likely in absentia) in March 2020: see L Harding, 'Three Russians and one Ukrainian to face MH17 murder charges', The Guardian, 19 June 2019.

${ }^{66}$ See, eg, JM Lemnitzer, 'International Commissions of Inquiry and the North Sea Incident: A Model for a MH17 Tribunal?' (2016) 27 EJIL 923 (invoking the North Sea Incident Commission of 1905 as precedent for a legallyoriented international commission of inquiry); S Williams, 'MH17 and the International Criminal Court: A Suitable Venue?' (2016) 17 Melb J Intl L 210.

${ }^{67}$ Rome Statute of the International Criminal Court (adopted 17 July 1998, entered into force 1 July 2002), 2187 UNTS 3.

${ }^{68}$ See https://www.icc-cpi.int/itemsDocuments/997/declarationVerkhovnaRadaEng.pdf.

${ }^{69}$ See https://www.icc-cpi.int/iccdocs/other/Ukraine Art 12-3 declaration 08092015.pdf.

${ }^{70}$ Art 53(1) of the Rome Statute.

${ }^{71}$ At the time of writing, the most recent outline of the process is OTP, Report on Preliminary Examination Activities 2018, [59]-[98].

${ }^{72}$ Arts 12(2)(a) and 12(3) of the Rome Statute. Ukraine's Article 12(3) declaration grants the Court jurisdiction over acts 'committed in the territory of Ukraine': see above n 69.
} 
to clarify which war crimes provisions of the Rome Statute are applicable. ${ }^{73}$ This may require consideration of the territorial dispute over Crimea (including whether Crimea is Ukrainian territory that is occupied by Russia) and the degree of Russian control over separatists in eastern Ukraine. With respect to Crimea, in its 2016 report on preliminary examinations, the OTP stated:

The information available suggests that the situation within the territory of Crimea amounts to an international armed conflict between Ukraine and the Russian Federation. This international armed conflict began at the latest on 26 February when the Russian Federation deployed members of its armed forces to gain control over parts of Ukrainian territory without the consent of the Ukrainian Government. The law of international armed conflict would continue to apply after 18 March 2014 to the extent that the situation within the territory of Crimea and Sevastopol factually amounts to an ongoing state of occupation. ${ }^{74}$

With respect to eastern Ukraine, in its 2016 report on preliminary examinations, the OTP held that, based on the information available, the conditions for the existence of a non-international armed conflict had been met. ${ }^{75}$ In addition, it held that there was some evidence that an international armed conflict between Russia and Ukraine existed in the region as a result of direct military engagements between the two states. ${ }^{76}$ Importantly, the OTP also noted:

For the purpose of determining whether the otherwise non-international armed conflict could be actually international in character, the Office is also examining allegations that the Russian Federation has exercised overall control over armed groups in eastern Ukraine ... In conducting its analysis, the Office must assess whether the information available indicates that Russian authorities have provided support to the armed groups in the form of equipment, financing and personnel, and also whether they have generally directed or helped in planning actions of the armed groups in a manner that indicates they exercised genuine control over them. ${ }^{77}$

Interestingly, though it recognises the relevance of the status of Crimea for the purposes of the applicable law, the OTP does not appear to have considered the preliminary question of the status of Crimea for the purposes of determining whether it is part of Ukraine's 'territory' and thus within Ukraine's Article 12(3) conferral of jurisdiction. This is notwithstanding its recognition that ICC jurisdiction is limited to crimes committed within the territory of Ukraine. ${ }^{78}$ As explained above, should a case concerning Crimea reach the Court, the (pre-) Trial Chamber would likely need to consider the status of Crimea both as a preliminary jurisdictional matter and as a consideration at the merits stage when determining the applicable law.

\section{THREE APPROACHES TO DISAGGREGATION}

\footnotetext{
73 OTP, Report on Preliminary Examination Activities 2016, [154].

${ }^{74}$ Ibid, [158] (emphasis added). See also OTP, Report on Preliminary Examination Activities 2018, [68].

75 OTP, Report on Preliminary Examination Activities 2016, [168]. Those conditions are that the violence must have reached a certain level of intensity and that the non-state armed groups must be sufficiently organised: S Sivakumaran, The Law of Non-International Armed Conflict (OUP 2012) 164-80.

76 OTP, Report on Preliminary Examination Activities 2016, [169].

77 Ibid, [170]. See also OTP, Report on Preliminary Activities 2018, [73]. On the modalities by which a noninternational armed conflict becomes internationalized, see K Mačák, Internationalized Armed Conflicts in International Law (OUP, Oxford 2018).

78 OTP, Report on Preliminary Examination Activities 2017, [83].
} 
It is clear from the preceding section that many of the specific legal claims arising out of the Ukraine/Russia dispute over Crimea and eastern Ukraine potentially implicate that broader dispute. This raises the question as to what impact any such relationship between these claims and the broader inter-state dispute might have on the jurisdiction of the tribunals. Put differently, what are the consequences of the disaggregation of disputes for the ability of international tribunals to rule on particular legal claims?

The approach that each of the tribunals above takes to this issue varies (not only across tribunals, but also across case law of individual tribunals). Three broad approaches are, however, discernible: first, the severability approach, whereby the tribunal explicitly isolates the particular claim, over which it has jurisdiction, from the broader dispute, over which it does not; second, the restrictive approach, whereby the tribunal considers the specific claim to be inseparable from the broader dispute, thereby depriving it of jurisdiction over the specific claim; third, the expansive approach, whereby the tribunal appears willingly to pronounce on matters over which it would not separately have jurisdiction where it is necessary to do so in addressing the claims over which it does have jurisdiction.

Each approach is discussed in turn. The ongoing nature of the Ukraine/Russia litigation means that many of these tribunals are yet to make any pronouncements in the context of this dispute. The analysis that follows, however, considers the approach that has been adopted to such issues across the jurisprudence of different tribunals. The three approaches thus represent a general framework of relevance beyond the particular Ukraine/Russia cases.

\section{A. The severability approach}

The severability approach broadly describes those cases in which a tribunal recognises that its jurisdiction is limited to addressing the specific claims before it and not other aspects of the broader dispute to which those claims relate, but that jurisdiction over those specific claims can still be exercised as those claims are separable from the broader dispute. Amongst the tribunals seised of the Ukraine/Russia claims, the ICJ, the W'TO dispute settlement system, and investment arbitrations have all followed this approach in particular cases.

Regarding the ICJ, notwithstanding references to other allegations against Russia in Ukraine's application, ${ }^{79}$ the Court, in its order on provisional measures,${ }^{80}$ emphasised the restricted form in which the core legal claims were brought and its limited jurisdiction in the case:

The context in which the present case comes before the Court is well known. In large parts of eastern Ukraine, that context is characterized by periods of extensive fighting which, as the record before the Court demonstrates, has claimed a large number of lives. The destruction, on 17 July 2014, of Malaysia Airlines Flight MH17 while it was flying over Ukrainian territory en route between Amsterdam and Kuala Lumpur, caused the deaths of 298 people. The Court is well aware of the extent of this human tragedy. Nevertheless, the case before the Court is limited in scope. In respect of the events in the eastern part of its territory, Ukraine has brought proceedings only under the ICSFT. With regard to the events in Crimea, Ukraine's claim is based solely upon CERD and the Court is not called upon, as Ukraine expressly recognized, to rule upon any issue other than allegations of racial discrimination. ${ }^{81}$

\footnotetext{
79 See above at text to $\mathrm{n} 15$.

${ }^{80}$ On filing its application to the Court, Ukraine also filed a request for the indication of provisional measures relating to Russia's compliance with both the CERD and ICSFT. After finding prima facie jurisdiction under both treaties, it went on to indicate certain provisional measures concerning the CERD, but held that Ukraine had not met the plausibility of claims requirement for the indication of provisional measures concerning the ICSFT. See Ukraine $v$ Russia, Order (Provisional Measures) (n 19).

81 Ibid, [16].
} 
Consistent with its previous case law, ${ }^{82}$ the Court thus makes clear that its jurisdiction is both granted and limited by the two treaties under which the claims have been brought. ${ }^{83}$ The ICJ has been clear, however, that it may nonetheless look beyond the specific norms over which it has jurisdiction if necessary for their interpretation. ${ }^{84}$ As Lorand Bartels has noted, jurisdiction clauses (such as compromissory clauses) limit the principal norms, yet leave intact certain categories of incidental norms, ${ }^{85}$ the latter including norms used to interpret the former. ${ }^{86}$ There is, of course, a balance to be struck here. As the quote above from Sir Christopher Greenwood indicates, ${ }^{87}$ this balance is between ensuring that the Court can deal effectively with disputes (which could be undermined by omitting highly relevant extraneous rules), whilst simultaneously honouring the principle that states must consent to the jurisdiction of international tribunals. The controversy over the ICJ's approach to these issues in the Oil Platforms case indicates the difficulty with where to strike such a balance, and indeed many of the criticisms of the Oil Platforms judgment suggested that the Court displaced rather than interpreted the applicable law. ${ }^{88}$

Notwithstanding the quote above from the Court's provisional measures order in Ukraine v Russia, suggesting its strict adherence to its limited jurisdiction, Russia nevertheless objects to the Court exercising jurisdiction in that case. Thus, in its preliminary objections, Russia argues:

The invocation of the ICSFT and CERD is ... artificial. Ukraine has made plain its wish to bring its misplaced allegations of annexation and aggression before the Court or other tribunals, and the current claims merely constitute one of Ukraine's attempts inappropriately to shoehorn those allegations into one or more treaties that provide for compulsory dispute settlement. ${ }^{89}$

More specifically, Russia argues that Ukraine's invocation of the ICSFT as a basis for challenging alleged direct Russian support for terrorism 'constitutes an invitation to circumvent Russia's obvious lack of consent' to ICJ jurisdiction. ${ }^{90}$ With respect to Ukraine's CERD claims, Russia

\footnotetext{
82 See, eg, Bosnia v Serbia (n 21) [147] ('[t]he jurisdiction of the Court in this case is based solely on Article IX of the Convention ... It follows that the Court may rule only on the disputes between the Parties to which that provision refers ... It has no power to rule on alleged breaches of other obligations under international law, not amounting to genocide, particularly those protecting human rights in armed conflict.') Similarly, see Application of the Convention on the Prevention and Punishment of the Crime of Genocide (Croatia v Serbia), Judgment [2015] ICJ Rep 3, [85]; Jadhav Case (India v Pakistan) [2019] Judgment (Merits) of 17 July 2019, [36].

83 On the limiting effect of jurisdictional clauses, see Cannizzaro and Bonafé (n 1); M Papadaki, 'Compromissory Clauses as the Gatekeepers of the Law to be 'Used' in the ICJ and the PCIJ' (2014) 6 JIDS 560; Tams (n 1); L Bartels, 'Applicable Law and Jurisdiction Clauses: Where Does a Tribunal Find the Principal Norms Applicable to the Case Before It?' in T Broude and Y Shany (eds), Multisourced Equivalent Norms in International Law (Hart 2011); S Rosenne, The Law and Practice of the International Court of Justice 1920-2005 (Martinus Nijhoff 2006) 648-9.

${ }^{84}$ Croatia v Serbia (n 82) [85] (" $\left.\mathrm{t}\right]$ hat does not prevent the Court from considering, in its reasoning, whether a violation of international humanitarian law or international human rights law has occurred to the extent that this is relevant for the Court's determination of whether or not there has been a breach of an obligation under the Genocide Convention'). Similarly, see; Jadhav Case (n 82) [37]; Case Concerning Oil Platforms (Islamic Republic of Iran v United States) Judgment (Merits) [2003] ICJ Rep 161, [42]; Case Concerning Certain German Interests in Polish Upper Silesia (Germany v Poland), Judgment (Preliminary Objections) [1925] PCIJ (Ser A) No 6, 18.

${ }^{85}$ Bartels (n 83).

${ }^{86}$ See also Papadaki (n 83) 569-76; A Gourgourinis, 'The Distinction between Interpretation and Application of Norms in International Adjudication' (2011) 2 JIDS 31. Though note that Papadaki (n 83) at 576 still demonstrates the limitations placed by the compromissory clause on the extraneous rules that can enter the adjudicative process via interpretation.

${ }^{87}$ See above at text to $\mathrm{n} 2$.

88 See, eg, the critique in Oil Platforms (n 84), Separate Opinion of Judge Higgins, [49]; Oil Platforms, ibid, Separate Opinion of Judge Buergenthal, [29]; JA Green, ‘The Oil Platforms Case: An Error in Judgment?’ (2004) 9 JCSL 357, 375-7.

${ }^{89}$ Preliminary Objections (Russia) (n 20) [4] (references omitted).

90 Ibid, [129].
} 
submits that ' $\mathrm{t}]$ he real issue in the dispute between the parties does not concern racial discrimination but the status of Crimea" ${ }^{91}$ and that '[s]uch an issue does not fall within the Court's jurisdiction ratione materiae under CERD'. ${ }^{2}$

These objections are reminiscent of the same respondent's preliminary objection to Georgia's claims under the CERD in Georgia v Russia, ${ }^{93}$ where it argued that the true dispute between the two states was one concerning armed conflict, rather than racial discrimination; it thus invited the Court to characterise the dispute in this way, as opposed to one concerning the interpretation or application of the CERD, which would have resulted in a finding of no jurisdiction. ${ }^{94}$ Russia's objections in both Georgia $v$ Russia and Ukraine $v$ Russia are premised on the idea that the disaggregation or framing of the dispute has resulted in claims that misrepresent its true nature, and that the real dispute is one over which the Court lacks jurisdiction. This is not an uncommon objection to be raised by respondents in ICJ cases. ${ }^{95}$ In its order on provisional measures in Ukraine $v$ Russia, the Court did not share this view (which Russia had invoked at that stage in respect of the ICSFT specifically ${ }^{96}$ ), instead simply asserting that the factual allegations raised by Ukraine do appear prima facie to engage certain provisions of the ICSFT. ${ }^{97}$ Its view as to the severability of the claims under the CERD and ICSFT from the broader dispute between Ukraine and Russia thus enabled it to look at these claims in isolation. In much of its previous case law, the ICJ has taken a similar approach to this type of jurisdictional objection. ${ }^{98}$

The severability approach has also been taken by the WTO Appellate Body in certain previous cases. Thus, in Mexico - Soft Drinks, the Appellate Body was faced with a claim from Mexico that Mexico's WTO obligations towards the US were inapplicable as a result of the latter's illegal refusal to establish a NAFTA panel to resolve what was claimed to be the broader bilateral dispute with which the US' claims were allegedly inextricably linked. The Appellate Body held that examining such an argument

... would entail a determination whether the United States has acted consistently or inconsistently with its NAFTA obligations. We see no basis in the DSU [Dispute Settlement Understanding] for panels and the Appellate Body to adjudicate non-WTO

\footnotetext{
${ }^{91}$ Ibid, [295].

92 Ibid, [320].

${ }^{93}$ Case Concerning Application of the International Convention on the Elimination of All Forms of Racial Discrimination (Georgia $v$ Russian Federation), Preliminary Objections of the Russian Federation (Vol 1), 1 December 2009, [3.10].

${ }^{94}$ Ibid, [2.3].

95 Similar jurisdictional objections have been made by respondents in previous cases: eg the UK's objections in Case Concerning Questions of Interpretation and Application of the 1971 Montreal Convention Arising From the Aerial Incident at Lockerbie (Libyan Arab Jamahiriya v United Kingdom), Judgment (Preliminary Objections) [1998] ICJ Rep 9, [24]-[25]; ibid, Dissenting Opinion of Judge Sir Robert Jennings (supporting the UK's position that the case was wrongly brought under the Montreal Convention and thus that the Court lacked jurisdiction); Iran's objections in Case Concerning United States Diplomatic and Consular Staff in Tebran (United States v Iran), Judgment (Merits) [1980] ICJ Rep 3, [37]; the US' objections in Case Concerning Military and Paramilitary Activities in and Against Nicaragua (Nicaragua v United States), Judgment (Jurisdiction and Admissibility) [1984] ICJ Rep 392, [104]-[105]; the US' objections in Alleged Violations of the 1955 Treaty of Amity, Economic Relations, and Consular Rights (Iran v United States), Order, 3 October 2018, [34]-[35]; France's objections in Immunities and Criminal Proceedings (Equatorial Guinea v France), Judgment (Preliminary Objections), 6 June 2018, [60]-[61], [65]; Chile's objections in Obligation to Negotiate Access to the Pacific Ocean (Bolivia v Chile), Judgment (Preliminary Objection) [2015] ICJ Rep 592, [28]; Canada's objections in Fisheries Jurisdiction Case (Spain v Canada), Judgment (Preliminary Objections) [1998] ICJ Rep 432, [26]-[27]; the US' objections in Case Concerning Oil Platforms (Iran v United States), Preliminary Objection Submitted by the United States, 16 December 1993, [3.01].

96 Ukraine v Russia, Order (Provisional Measures) (n 19) [70].

97 Ibid, [29]-[31].

${ }^{98}$ See, eg, United States v Iran (n 95) [37]; Nicaragua v United States (n 95) [104]-[105]; Application of the Interim Accord of 13 September 1995 (the Former Yugoslav Republic of Macedonia v Greece), Judgment (Merits) [2011] ICJ Rep 644, [37]; Case Concerning Application of the International Convention on the Elimination of All Forms of Racial Discrimination (Georgia v Russian Federation), Judgment (Preliminary Objections) [2011] ICJ Rep 70, [32]; Bolivia v Chile (n 95) [32]-[34]; Alleged Violations of the 1955 Treaty of Amity, Economic Relations, and Consular Rights (Iran v United States), Order, 3 October 2018, [38]; Case Concerning Oil Platforms (Iran v United States) [1996] ICJ Rep 803, Judgment (Preliminary Objections), [18]-[21].
} 
disputes ... Accepting Mexico's interpretation would imply that the WTO dispute settlement system could be used to determine rights and obligations outside the covered agreements. ${ }^{99}$

It has been suggested that, ' $[\mathrm{w}]$ hile this statement probably went too far, confusing interpretation with adjudication ... the point for present purposes is that it clearly illustrates a deep reluctance on the part of the Appellate Body to be drawn into expressing an opinion on the content and meaning of international legal texts other than the covered agreements. ${ }^{100}$ Having refused to engage with Mexico's argument, the Appellate Body simply went on to assess the conformity of Mexico's measures against the WTO covered agreements alone. It thus appeared to sever the WTO claims from the NAFTA dispute, leaving it free to rule on the former.

As noted above, it does not appear that Ukraine raised any arguments in the Russia - Traffic in Transit proceedings that would have implicated the broader dispute (and non-WTO norms, such as the prohibitions on intervention and the use of force). ${ }^{101}$ However, should such arguments be raised in other WTO proceedings, it is not clear precisely what approach the Appellate Body would take. It may be that, as with its other jurisprudence, the Appellate Body would be willing to take account of non-WTO norms in order to interpret Article XXI GATT. ${ }^{102}$ Alternatively, it may follow its approach from Mexico - Soft Drinks and apply the WTO covered agreements whilst refusing to engage with non-WTO arguments. Indeed, the panel in Russia - Traffic in Transit was keen to emphasise the inconsequential nature of its conclusions for the broader inter-state dispute. $^{103}$

Finally, the severability approach can most clearly be seen in the awards already issued by some of the Crimea investment tribunals. It has been reported that a number of the tribunals in these cases have found jurisdiction whilst claiming not to have ruled on the question of sovereignty over Crimea. ${ }^{104}$ Indeed, at the time of writing, seven tribunals have reportedly decided on the merits and found in favour of the claimants. ${ }^{105}$

${ }^{99}$ Mexico - Tax Measures on Soft Drinks and Other Beverages, WT/DS308/AB/R, 6 March 2006, [56].

100 A Lang, "Twenty Years of the WTO Appellate Body's 'Fragmentation Jurisprudence”" (2015) 14 J Intl Trade L \& Policy 116, 117.

101 See above at text to nn 52-4.

${ }^{102}$ It is clear that the Appellate Body has in previous jurisprudence drawn on non-WTO rules to interpret WTO rules: See, eg, United States -Shrimp (n 51) [127]-[134]; EC - Bananas III, WT/DS27/AB/R, 27 September 1997, [167]. On this, see L Bartels, 'Jurisdiction and Applicable Law in the WTO' (2016), Society of International Economic Law, Fifth Biennial Global Conference Working Paper No 2016/18; J Pauwelyn, 'How to Win a World Trade Organization Dispute Based on Non-World Trade Organization Law? Questions of Jurisdiction and Merits' (2003) 37 JW'T 997.

103 Russia - Traffic in Transit (n 48) [7.121] ("[t]he Panel notes that it is not relevant to this determination which actor or actors bear international responsibility for the existence of this situation to which Russia refers. Nor is it necessary for the Panel to characterize the situation between Russia and Ukraine under international law in general.') Similarly, see Russia - Railway Equipment (n 48) [7.210].

${ }^{104}$ R Kabra, 'Crimea-Related Lugzor v. Russia Arbitration Clears Jurisdictional Hurdles', LAReporter, 13 December 2017 (on the Limited Liability Company Lugzor et al $v$ The Russian Federation (n 55) tribunal); LE Peterson, 'In Jurisdiction Ruling, Arbitrators Rule that Russia is Obliged under BIT to Protect Ukrainian Investors in Crimea Following Annexation', LAReporter, 9 March 2017 (on the Aeroport Belbek. LLC et al $v$ The Russian Federation (n 55) and PJSC CB Privatbank and Finance Company Finilon LLC v The Russian Federation (n 55) tribunals); J Hepburn, 'Investigation: Full Jurisdictional Reasoning Comes to Light in Crimea-Related BIT Arbitration vs. Russia', LAReporter, 9 November 2017 (on the Everest Estate LLC et al $v$ The Russian Federation (n 55) tribunal); J Hepburn and R Kabra, 'Investigation: Further Russia Investment Treaty Decisions Uncovered, Offering Broader Window into Arbitrators’ Approaches to Crimea Controversy', IAReporter, 17 November 2017 (on the PJSC Ukrnafta v The Russian Federation (n 55) and Stabil LLC et al $v$ The Russian Federation (n 55) tribunals).

${ }^{105}$ Everest Estate LLC et al $v$ Russia (n 55), on which see LE Peterson, 'Russia Held Liable in Confidential Award for Expropriation of Hotels, Apartments and Other Crimean Real Estate; Arbitrators Award Approximately \$150 Million (Plus Legal Costs) for Breach of Ukraine Bilateral Investment Treaty', LAReporter, 9 May 2018; Oschadbank v Russia, on which see 'Russian Federation is Hit with \$1.3 Billion UNCITRAL Bilateral Investment Treaty Award', LAReporter, 26 November 2018; Belbek \& Kolomoisky v Russia and PJSC CB PrivatBank \& Finilon v Russia (n 55), on which see LE Peterson, 'Russia Held Liable for Expropriation of Bank Operations in Billion Dollar Arbitration, As Well As of 
It appears that in the jurisdictional decisions, at least some of the tribunals determined that 'territory' under the BIT could be defined solely for the purpose of the BIT as including territory over which one of the parties to the BIT exercises effective control, ${ }^{106}$ whether lawful or unlawful. ${ }^{107}$ Reports concerning the PJSC Ukrnafta $v$ The Russian Federation and Stabil LLC et al $v$ The Russian Federation jurisdictional decisions give some detail on the reasoning of the tribunals, noting that they held that Russia exercised effective control over Crimea through physical and legal acts, which, for the purposes of the BIT, was sufficient to constitute Russian 'territory'. ${ }^{108}$ The tribunals made clear, however, that they did not have jurisdiction under Article 9 of the 1998 BIT to rule on the sovereignty question. ${ }^{109}$ Moreover, it appears that in its interventions, Ukraine argued that, though Crimea is a part of sovereign Ukrainian territory, Russia's de facto control of the peninsula renders it Russian 'territory' for the purposes of the BIT. ${ }^{110}$ Indeed, an attempt by Russia to have these partial awards set aside in the Swiss Federal Tribunal was rejected, with the Tribunal holding that the arbitral tribunals did not err in finding that the BIT applied to Crimea. ${ }^{111}$

These investment tribunals have thus accepted jurisdiction in cases implicating ancillary (territorial) disputes, but on the basis that they view the BIT as self-contained, with 'territory' capable of interpretation for the purposes of the BIT alone and without further consequence. ${ }^{112}$ In this sense, these cases, as with those of the ICJ and WTO that were discussed above, fully embrace disaggregation, with the specific legal claims considered wholly separable from other aspects of the broader dispute.

\section{B. The restrictive approach}

The restrictive approach covers those cases in which a tribunal considers the specific claims over which it appears to have jurisdiction to be inseparable from other aspects of a dispute over which it does not have jurisdiction, resulting in the tribunal declining to exercise jurisdiction even over

\footnotetext{
Airport', LAReporter, 15 February 2019; NJSC Naftogaz v Russia (n 55), on which see D Charlotin, 'In New BIT Ruling, Russia Found Liable for Expropriation of Naftogaz Assets', LAReporter, 1 March 2019; PJSC Ukrnafta v Russia and Stabil v Russia ( $\mathrm{n}$ 55), on which see LE Peterson, 'As Russia is Held Liable in Two New BIT Cases, and Ordered to Pay Upwards of \$100 Million, We Round-Up Developments in Crimea-Related Arbitrations’, LAReporter, 16 April 2019.

106 This is similar to the Strasbourg Court's interpretation of art 1 ECHR jurisdiction, which it views as including territory over which a state exercises effective control, eschewing (in theory) the need to consider questions of sovereignty: Al-Skeini (n 42).

107 Peterson, 'In Jurisdiction Ruling' (n 104); Hepburn and Kabra, 'Investigation: Further Russia Investment Treaty Decisions Uncovered' (n 104).

${ }^{108}$ Hepburn and Kabra, 'Investigation: Further Russia Investment Treaty Decisions Uncovered', ibid.

109 See the outline of the award given in Russia v A et al (Beschwerde gegen den Zwischenentscheid des Schiedsgerichts mit Sitz in Genf vom 26 Juni 2017 (Nr. 2015-35)) (Swiss Federal Tribunal), 4A_398/2017, Judgment of 16 October 2018, [4.2] (judgment in German).

${ }^{110}$ Hepburn, 'Investigation: Full Jurisdictional Reasoning' (n 104) (in the Everest Estate LLC et al $v$ The Russian Federation (n 55) case); Peterson, 'In Jurisdiction Ruling' (n 104) (in the Aeroport Belbek LLC et al $v$ The Russian Federation (n 55) and PJSC CB Privatbank and Finance Company Finilon LLC v The Russian Federation (n 55) cases).

111 Russia v A et al (n 109) [4.3.2]; Russia v A (Beschwerde gegen den Zwischenentscheid des Schiedsgerichts mit Sitz in Genf vom 26 Juni 2017 (PCA Nr. 2015-34)), 4A_396/2017, Judgment of 16 October 2018 (Swiss Federal Tribunal) [4.3.2] (judgment in German). For discussion, see L Bohner, 'In Now-Public Decisions, Swiss Federal Tribunal Clarifies Reasons for Dismissing Challenges to Two Crimea-Related Investment Treaty Awards Against Russia', LAReporter, 16 November 2018.

112 Reports of the Everest Estate LLC et alv The Russian Federation (n 55) jurisdictional decision suggest a slightly different emphasis in the reasoning, such that the tribunal determined that the 1998 BIT applies to Crimea on the basis that no party explicitly objected: Jarrod Hepburn, 'Investigation: Full Jurisdictional Reasoning' (n 104). The Ukrainian Supreme Court upheld enforcement of the final Everest award in Ukraine: LE Peterson, 'Russia Held Liable for Expropriation of Bank Operations in Billion Dollar Arbitration, As Well As of Airport', LAReporter, 15 February 2019. Russia's request to stay the enforcement of the awards was also refused by the Hague Court of Appeal, which specifically noted that the investment claims can be resolved without giving an opinion on the status of Crimea: The Russian Federation v Everest Estate LLC et al, Case No 200.250.714-01, Judgment of 11 June 2019 (in Dutch).
} 
the former. In contrast to the severability approach, therefore, the restrictive approach does not accept that each aspect of the broader dispute can be disaggregated so as to leave intact jurisdiction over specific elements of that dispute. This restrictive approach can be seen in some case law of both the ICJ and UNCLOS tribunals.

The ICJ's clear support for the severability approach in both its provisional measures order in Ukraine v Russia and in earlier cases was set out above. ${ }^{113}$ However, there is also previous authority that the Court will reject jurisdiction in certain cases where either the 'very essence of the dispute' is something other than that over which the Court has jurisdiction (with the latter being only a secondary question), ${ }^{114}$ or, more basically, where addressing the question put to it requires a pre-determination of a different matter over which the Court has not been granted jurisdiction. ${ }^{115}$ As Peter Tzeng has noted, ${ }^{116}$ these tests bear a clear similarity to the tests adopted by the Court in its case law addressing the indispensable third party principle. ${ }^{117}$

Russia's jurisdictional objection before the ICJ, which, as noted, challenges the framing or characterisation of its dispute with Ukraine as one concerning the ICSFT and CERD, ${ }^{118}$ is not entirely analogous to these previous ICJ cases. The Interim Accord and Malaysia/Singapore cases are concerned with the slightly different situation where the Court is called upon to make a prior determination about a different dispute over which it has not been granted jurisdiction so that it might then rule on the matter over which it has been granted jurisdiction. The Court's reasoning in the Aegean Sea case is closer in nature to Russia's objection, as it raises the question about how to characterise a dispute ('the very essence of the dispute'). Its focus, however, again appears to be on cases where the actual claim over which the Court has jurisdiction is something that can only be decided after resolving the 'true' dispute over which the Court does not have jurisdiction. In any event, though it was shown above that the existence of a broader dispute does not itself preclude the ICJ from dealing with the specific claim over which it has jurisdiction, ${ }^{119}$ it is clear that there are limits to the ICJ's willingness to deal with one specific claim that arises from a broader dispute.

As with the claims before the ICJ, Russia similarly objects that Ukraine's 2016 UNCLOS claims before the Annex VII tribunal mischaracterise the 'real dispute', which, Russia argues, is 'the dispute with respect to sovereignty over land territory', and that 'the determination of that dispute is the unavoidable prerequisite to addressing the specific [UNCLOS] claims'. ${ }^{120}$ Such

\footnotetext{
113 See above at text to nn $97-8$.

114 Aegean Sea (n 27) [83]-[86] (concerning a reservation to Greece's acceptance of the compromissory clause, which excluded any 'dispute relating to the territorial status of Greece'; the Court held Greece's application to fall within this reservation, given that it concerned a dispute over continental shelf rights, which necessarily implicated territorial rights).

115 Interim Accord (n 98) [37] (though the Court upheld jurisdiction, stating that 'a relationship between the dispute submitted to the Court and the name difference [the subject of a reservation to the compromissory clause] does not suffice to remove that dispute from the Court's jurisdiction', it is included here as the Court explicitly recognised that 'if the Court were called upon to resolve specifically the name difference, or to express any views on this particular matter', then it would lack jurisdiction over the entire case); Sovereignty over Pedra Branca/Pulau Batu Puteh, Middle Rocks and South Ledge (Malaysia/Singapore) [2008] ICJ Rep 12, [297]-[299] (the Court declined to determine the sovereignty over South Ledge, a low-tide elevation, as this would require it to delimit the territorial waters of Malaysia and Singapore, and the special agreement granting the Court jurisdiction referred only the sovereignty dispute to the Court).

116 Tzeng (n 12).

117 Case of the Monetary Gold Removed from Rome in 1943 (Italy v France, United Kingdom, and United States), Judgment (Preliminary Objections) [1954] ICJ Rep 19, 32-3; Case Concerning Certain Phosphate Lands in Naura (Nauru v Australia), Judgment (Preliminary Objections) [1992) ICJ Rep 240, [49]-[55]; Case Concerning East Timor (Portugal v Australia), Judgment [1995] ICJ Rep 90, [34]-[35].

118 See above at text to nn 89-92.

${ }^{119}$ See above at text to $\mathrm{n} 98$.

120 Dispute Concerning Coastal State Rights in the Black Sea, Sea of Azov, and Kerch Strait (Ukraine v The Russian Federation), Preliminary Objections of the Russian Federation: Volume I, 19 May 2018, [42]. See also Dispute Concerning Coastal
} 
disputes are, Russia claims, outside the jurisdiction of UNCLOS tribunals as they do not concern the 'interpretation or application' of the Convention. ${ }^{121}$ UNCLOS tribunals have faced similar jurisdictional objections (that maritime claims implicate territorial sovereignty disputes) in certain previous cases, ${ }^{122}$ where one can see the restrictive approach again being endorsed. ${ }^{123}$

The Mauritius v United Kingdom and Philippines v China awards concerned UNCLOS claims of this nature, and whilst both endorse a restrictive approach to jurisdiction, they differ in their reasoning and in their conclusions on the facts. ${ }^{124}$ In the former case, Mauritius brought a claim against the UK for the latter's creation of a marine protected area (MPA) around the Chagos archipelago, alleging, in its first submission, that the UK is not permitted to declare an MPA as it is not the 'coastal state'. ${ }^{125}$ In precisely the same way as in the Ukraine $v$ Russia case before the Annex VII tribunal, the question of territorial sovereignty thus appeared to be implicated. The UK, similar to Russia's response to Ukraine's applications to the ICJ and the Annex VII tribunal, objected that Mauritius' first submission reflected 'an artificial re-characterization of the longstanding sovereignty dispute as a "who is the coastal State" dispute. ${ }^{126}$ Mauritius, on the other hand, argued that it was merely requesting the Tribunal to interpret a term within UNCLOS, that of 'coastal state'. ${ }^{127}$

The Tribunal held that it needed to determine the proper characterization of the dispute in order to determine whether it has jurisdiction (i.e. whether the dispute was concerned primarily with the interpretation and application of UNCLOS or with sovereignty). ${ }^{128}$ On the basis of the historical record of the dispute and the consequences of determining that the UK was not the coastal state (considered to extend beyond the validity of the MPA), the Tribunal concluded that 'the Parties' dispute with respect to Mauritius' First Submission is properly characterized as relating to land sovereignty over the Chagos Archipelago. ${ }^{129}$ It then held that, where the 'real issue in the case' and the 'object of the claim' do not relate to the Convention, an 'incidental connection' to the Convention cannot bring the dispute within the tribunal's jurisdiction. ${ }^{130}$ Applying this test, the Tribunal concluded that, though 'in some instances a minor issue of territorial sovereignty could indeed be ancillary to a dispute concerning the interpretation or application of the Convention',

State Rights in the Black Sea, Sea of Azov, and Kerch Strait (Ukraine v The Russian Federation), Reply of the Russian Federation to the Written Observations and Submissions of Ukraine on Jurisdiction: Volume I, 28 January 2019, [16].

${ }^{121}$ UNCLOS, art 288(1); Ukraine v The Russian Federation, Preliminary Objections of the Russian Federation, ibid, [47]. In addition to its principal objection concerning the character of the dispute, Russia puts forward further preliminary objections, including its claim that the Sea of Azov and Kerch Strait are internal waters and its view as to the interpretation of the Article 298 UNCLOS declarations that both Ukraine and Russia have made: Ukraine v The Russian Federation, Preliminary Objections of the Russian Federation (n 120).

${ }^{122}$ For analysis, see I Buga, 'Territorial Sovereignty Issues in Maritime Disputes: A Jurisdictional Dilemma for Law of the Sea Tribunals' (2012) 27 Intl J Marine \& Coastal L 59; Volterra et al (n 11); P Tzeng, 'Ukraine v. Russia and Philippines v. China: Jurisdiction and Legitimacy' (2017) 46 Denver J Intl L \& Policy 1.

${ }^{123}$ Commentators are divided on whether UNCLOS tribunals can make incidental determinations regarding territorial disputes as part of an UNCLOS claim. See, eg, R Wolfrum, Statement to the Informal Meeting of Legal Advisers of Ministries of Foreign Affairs, New York, 23 October 2006; T Treves, 'What Have The United Nations Convention and The International Tribunal for the Law of the Sea To Offer As Regards Maritime Delimitation Disputes?' in R Lagoni and D Vignes (eds), Maritime Delimitation (Martinus Nijhoff, Leiden 2006) 77; BH Oxman, 'The Third United Nations Conference on the Law of the Sea: The Ninth Session' (1981) 75 AJIL 211, 233; S Talmon, 'The South China Sea Arbitration: Is There a Case to Answer?' in S Talmon and BB Jia (eds), The South China Sea Arbitration: A Chinese Perspective (2014) 46-8.

${ }^{124}$ Chagos Marine Protected Area Arbitration (Mauritius v United Kingdom), PCA Case No. 2011-03, Award, 18 March 2015; The South China Sea Arbitration (The Republic of Philippines v The People's Republic of China), PCA Case No. 2013-19, Award on Jurisdiction and Admissibility, 29 October 2015.

125 Mauritius v UK, ibid, [158].

126 Ibid, [207].

127 Ibid.

${ }^{128}$ Ibid, [211].

${ }^{129}$ Ibid, [212].

130 Ibid, [220]. 
and thus within an UNCLOS tribunal's jurisdiction, that was not the case here; it therefore considered itself to be without jurisdiction over Mauritius' first submission. ${ }^{131}$

Whereas the Tribunal in Mauritius v UK thus focused entirely on the character of the dispute ('the real issue in the case'), a slightly different approach was taken by the tribunal in Philippines $v$ China. In this case, China, like the UK in Mauritius v UK and Russia in both the ICJ and UNCLOS Ukraine $v$ Russia cases, raised concerns with the disaggregation of the broader inter-state dispute and objected that the true dispute was not that over which the tribunal had jurisdiction. ${ }^{132}$ The Tribunal stated that ' $[t]$ he nature of the dispute may have significant jurisdictional implications, including whether the dispute can fairly be said to concern the interpretation or application of the Convention' and that it is for the Tribunal to determine the characterization of the dispute based on the submissions of the parties and other relevant evidence. ${ }^{133}$ Importantly, the Tribunal began by emphasising that the existence of a sovereignty dispute between the parties did not mean that the claims before it were properly to be characterised as relating to sovereignty: 'the Parties can readily be in dispute regarding multiple aspects of the prevailing factual circumstances or the legal consequences that follow from them. ${ }^{, 134}$ It then held that it

... might consider that the Philippines' Submissions could be understood to relate to sovereignty if it were convinced that either (a) the resolution of the Philippines' claims would require the Tribunal to first render a decision on sovereignty, either expressly or implicitly; or (b) the actual objective of the Philippines' claims was to advance its position in the Parties' dispute over sovereignty. ${ }^{135}$

Thus, whereas the Mauritius v UK Tribunal relied solely on the characterisation of the dispute, the Tribunal in Philippines $v$ China also considered a dispute to be outside its jurisdiction where the sovereignty question (though not the actual objective of the claims) must still be answered in order to rule on the UNCLOS claim. On the facts, it held neither of these to be the case as the Philippines had not asked the Tribunal to rule on sovereignty, nor was such a ruling implicitly required to address the Philippines' submissions. ${ }^{136}$

The factual similarity between Mauritius $v U K$ and Ukraine $v$ Russia might lead the Tribunal in the latter to follow the purely characterisation-based approach of the former, and it may well come to the same conclusion. Ukraine, however, argues that its claims are based on UNCLOS and that Russia's objection that the real dispute is a sovereignty dispute is inadmissible and implausible given the international community's rejection of its annexation of Crimea in the General Assembly; this is in contrast to the long-running sovereignty dispute that was the context for the Mauritius $v$ UK case. ${ }^{137}$ Should the Tribunal follow this argument, it might view the facts as closer to those

\footnotetext{
131 Ibid, [221].

132 'Position Paper of the Government of the People's Republic of China on the Matter of Jurisdiction in the South China Sea Arbitration Initiated by the Republic of the Philippines' (2016) 16 Chinese J Intl L 431, 432 [3] and 439 [29].

133 Philippines v China (n 124) [150].

${ }^{134} \mathrm{Ibid},[152]$. This is similar to the ICJ jurisprudence cited above to the effect that it is no impediment to a legal claim that that claim forms part of a broader dispute, i.e. disaggregation of disputes itself is not a problem for exercising jurisdiction over specific legal claims: see, eg, Georgia v Russia (n 98) [32].

135 Philippines v China (n 124) [153].

${ }^{136}$ Ibid. Though Philippines $v$ China could therefore be seen as promoting the severability approach to these issues, it is included here as its reasoning indicates that UNCLOS tribunals might refuse jurisdiction in certain of these cases.

137 Dispute Concerning Coastal State Rights in the Black Sea, Sea of Aqov, and Kerch Strait, Written Observations and Submissions of Ukraine on Jurisdiction (n 26) [13]-[60]. Similarly, see D Koval and VJ Schatz, 'Ukraine v. Russia: Passage Through Kerch Strait and the Sea of Azov, Part III: The Jurisdiction of the Arbitral Tribunal', Volkerrechtsblog, 15 January 2018.
} 
cases recognised in Mauritius $v U K$ in which a minor incidental sovereignty question may be resolved where the key issue concerns UNCLOS rights. ${ }^{138}$

Alternatively, should the Tribunal follow the approach in Philippines v China, this could either support or undermine Ukraine's claims. On the one hand, Philippines v China explicitly recognised the co-existence of maritime and sovereignty claims and the possibility of separating the two. ${ }^{139}$ On the other hand, in addition to the characterisation approach, the Tribunal also held that an UNCLOS tribunal would lack jurisdiction if any decision on sovereignty is a necessary precursor to addressing the UNCLOS claim, ${ }^{140}$ which, as stated above, is likely to be the case here. This appears a stricter test than that in Mauritius $v U K$.

To conclude, there are some interesting parallels between the approaches of the UNCLOS tribunals and the ICJ in cases endorsing this restrictive approach. Whilst both Philippines v China and the ICJ explicitly recognise that the disaggregation of disputes need not raise jurisdictional problems where they are entirely separable, discrete legal claims, ${ }^{141}$ it is also clear that the UNCLOS cases reflect a similar (though perhaps greater ${ }^{142}$ ) concern to some of the ICJ jurisprudence cited above where the claims are considered inseparable from the broader dispute. In both fora, this concern has focused on the characterisation of the dispute- the "very essence of the dispute ${ }^{\text {143 }}$ or the 'real issue in the case ${ }^{144}$ - as well as the question of whether a prior determination is needed of an incidental matter that itself is outside the jurisdiction of the tribunal. ${ }^{145}$ Such approaches suggest that the disaggregation of broader disputes into discrete legal claims can have a limiting effect on the jurisdiction of international tribunals.

\section{The expansive approach}

The final approach to these issues that can be seen in particular cases is referred to here as the expansive approach. This refers to those cases in which a particular tribunal, faced with a claim that implicates other aspects of a broader dispute over which it would not otherwise have jurisdiction, nevertheless exercises jurisdiction over the specific claim and, importantly, does not shy away from making other determinations regarding that broader dispute.

The expansive approach can especially be seen in the case law of the ECtHR. It was noted above that the pending ECHR claims (both inter-state and individual) will likely implicate the broader inter-state dispute concerning alleged Russian interference in eastern Ukraine and (potentially) the sovereignty dispute over Crimea. This notwithstanding, the ECtHR's previous case law that was noted above ${ }^{146}$ indicates that it is unlikely to view this as a challenge to its jurisdiction over the ECHR claims themselves; this is in contrast to the restrictive approach, which, as noted, sees such incidental matters as undermining the tribunals' jurisdiction even over the specific claims. Moreover, the Strasbourg Court's case law suggests that it will also not shy away from making determinations over those incidental matters, in contrast to the severability approach,

\footnotetext{
138 Mauritius v UK (n 124) [221]. Suggesting this, see Dispute Concerning Coastal State Rights in the Black Sea, Sea of Aqov, and Kerch Strait, Written Observations and Submissions of Ukraine on Jurisdiction (n 26) [51].

139 Philippines v China (n 124) [152].

140 Ibid, [153].

${ }^{141}$ See, eg, Georgia v Russia (n 98) [32]; Philippines v China (n 124) [152].

${ }^{142}$ For a particularly restrictive approach to disaggregation and jurisdiction in UNCLOS proceedings, see Southerm Bluefin Tuna Case (Australia and New Zealand v Japan) (Award on Jurisdiction and Admissibility), 4 August 2000 (2000) 39 ILM 1359, [54] (the Annex VII tribunal held that it would be 'artificial' to treat Australia and New Zealand's UNCLOS claims as separate from claims arising under a different treaty over which the tribunal did not have jurisdiction; it therefore concluded that it could not exercise jurisdiction over those UNCLOS claims due to its view as to the operation of a dispute settlement provision in that other treaty). This decision has been criticised: see, eg, A Boyle, 'The Southern Bluefin Tuna Arbitration' (2001) 50 ICLQ 447.

143 Aegean Sea (n 27) [83].

144 Mauritius v UK (n 124) [220].

145 Philippines v China (n 124) [153]; Malaysia/Singapore (n 115) [297]-[299].

146 See above at text to nn 40-3.
} 
which, as noted, emphasises the separability of the specific claims and the tribunals' determinations thereunder from the broader dispute. Thus, its northern Cyprus and Transdniestria cases confirm a willingness on the part of the ECtHR to address incidental questions of territorial sovereignty in order to rule on the specific claims within its jurisdiction. ${ }^{147}$ Similarly, the Court in these cases willingly ruled on the extent of foreign state intervention (including, in Transdniestria, control of separatists) in order to determine whether jurisdiction existed under the Convention. ${ }^{148}$

This expansive approach to jurisdiction can also be seen in the approach of the ICC's OTP in relation to its preliminary examination into the situation in Ukraine, as well as in some previous jurisprudence of international criminal tribunals. The possibility of the inter-state Ukraine/Russia dispute being implicated in the ICC proceedings, with respect both to jurisdiction and applicable law, was noted above. ${ }^{149}$ It is clear from its reports on preliminary activities that the OTP considers incidental determinations about the status of Crimea (i.e. whether or not it is occupied and thus not sovereign Russian territory) and the extent of Russian control over insurgent groups in eastern Ukraine to fall within the jurisdiction of the ICC. ${ }^{150}$

It remains to be seen what approach the ICC might take to such issues, i.e. whether it will follow the expansive approach suggested by the OTP, the severability approach followed in much ICJ case law and the Crimea BIT arbitrations, or the restrictive approach of the UNCLOS tribunals and certain ICJ cases. It could be instructive to look at previous case law of the International Criminal Tribunal for the former Yugoslavia (ICTY) concerning the required level of control over non-state groups by a foreign state for an apparently non-international armed conflict to be considered international in character. This jurisprudence certainly suggests a willingness by (some) international criminal tribunals to make determinations that those tribunals consider as having implications beyond the particular case at hand. Thus, the ICTY famously took the view that the test for the level of foreign state control of armed groups required for a conflict to be considered international was equivalent to the test for state responsibility for the conduct of individuals under their control, such that any determination as to the former was seen as necessarily making a determination regarding the latter. ${ }^{151}$ Though the ICC has applied the same 'overall control' test as the ICTY in such situations, it has not taken a position on whether this is considered to be relevant only for the purposes of determining the applicable law before the ICC, or whether it is also viewed as implicating the controlling state's responsibility under international law. ${ }^{152}$

Interestingly, (pre-) Trial Chambers are likely to face similar issues regarding the scope of their jurisdiction in other contexts, such as any future case relating to Palestine where questions of statehood might be raised as a preliminary objection, ${ }^{153}$ or cases concerning the crime of aggression, which necessarily would implicate state responsibility. ${ }^{154}$

${ }_{147}$ Loiridou v Turkey, App No 15318/89, Judgment of 18 December 1996 (Grand Chamber), [44]; Ilaşcu (n 41) [330][331]; Catan (n 41) [109]-[110]; Sandu (n 41) [34]-[35].

148 Ilasscu (n 41) [392]; Catan (n 41) [122]; Sandu (n 41) [36]-[37]; Loizidou, ibid, [56] (though note that here the Court did emphasise that it did not need to rule on the legality or illegality of Turkey's military intervention, thus following the severability approach in that respect).

${ }^{149}$ See above at text to nn $72-7$.

${ }^{150}$ See above at text to nn 74 and 77.

151 Prosecutor v Tadic (Judgment) IT-94-1A, Appeals Chamber (15 July 1999) [98]. The ICJ disagreed, viewing the two tests as separate and without consequence for one another: Bosnia v Serbia (n 21) [403]-[405]. On this, see R Jorritsma, 'Where General International Law Meets International Humanitarian Law: Attribution of Conduct and the Classification of Armed Conflicts' (2018) 23 JCSL 405.

152 Prosecutor v Germain Katanga (Judgment) ICC-01/04-01/07, Trial Chamber (7 March 2014), [1178]; Prosecutor v JeanPierre Bemba Gombo (Judgment) ICC-01/05-01/08, Trial Chamber (21 March 2016) [130].

${ }^{153}$ The OTP, for the purposes of Palestine's Article 12(3) declarations and accession to the Rome Statute, has simply followed the UNGA's designations of Palestine, first as an observer entity and subsequently as a non-member observer state, in determining whether Palestine is a 'state' for the purposes of Article 12 of the Rome Statute: ICC Press Release, 'The Prosecutor of the International Criminal Court, Fatou Bensouda, opens a preliminary examination of the situation in Palestine', ICC-OTP-20150116-PR1083, 16 January 2015.

${ }^{154}$ See, eg, D Akande and A Tzanakopoulos, 'Treaty Law and ICC Jurisdiction over the Crime of Aggression' (2018) 29 EJIL 939, 959 (acknowledging the consent-based concerns with the ICC exercising jurisdiction over the crime of 


\section{UNDERSTANDING THE DIFFERENT APPROACHES TO DISAGGREGATION}

The three approaches discussed above (severability, restrictive and expansive) reflect very different ways of engaging with the phenomenon of disaggregation of disputes in international law and its impact on jurisdiction. In particular, they reflect different approaches to where the balance referred to by Sir Christopher Greenwood lies - the severability and restrictive approaches might be viewed as the most faithful to the principle of consent, whereas the expansive approach might be seen as more appropriate from the perspective of the effective resolution of disputes.

A number of explanations can be given for the varied approaches of the tribunals to these issues. First, it is clear that the substantive area of law at issue affects the approaches available to the tribunals. For example, the severability approach adopted by the ICJ in many cases and by the Crimea investment arbitrations was not available to the ICJ in Aegean Sea or the UNCLOS tribunal in Mauritius $v$ UK, given that those latter cases concerned law of the sea claims in which the land dominates the sea' principle is well established; in such cases, one often cannot sever maritime disputes from sovereignty disputes over adjacent land. ${ }^{155}$ In the case of WTO panels and the Appellate Body, Articles 3.2 and 19.2 of the Dispute Settlement Understanding have been seen as placing a particular restriction on their applicable law, including in Mexico - Soft Drinks, in which the Appellate Body viewed Mexico's invocation of NAFTA as inconsistent with those provisions. ${ }^{156}$

Second, each tribunal has different jurisdictional bases and terms of reference that necessarily affect how such matters are addressed. Indeed, the restrictive approach endorsed in the Aegean Sea and Interim Accord cases may well have been influenced by the fact that in both cases the respondent state objected that the claims fell within a reservation to their acceptance of the relevant compromissory clauses. ${ }^{157}$ In Malaysia/Singapore, the Court's jurisdiction was based on a special agreement between the two states by which they referred the sovereignty dispute to the Court, but not any delimitation of the territorial waters of the two states, the latter of which the Court determined would need to be answered in order to address the former. ${ }^{158}$ The jurisdictional remit of the particular tribunal is also particularly important for regime-specific tribunals, such as those under the WTO or UNCLOS, which have a clearly restricted subject-matter jurisdiction. ${ }^{159}$

These considerations provide some important context for understanding the approaches of the ICJ, UNCLOS tribunals, investment tribunals, and WTO dispute settlement system to these questions in the cases discussed above. However, they do not assist in explaining the different approaches of other tribunals, such as the ECtHR, in particular cases, whose jurisdiction is similarly limited by its constituent instrument. ${ }^{160}$ Some further explanation is therefore needed. One possibility is that the different approaches outlined above might be influenced by the different views of each of these tribunals as to their own roles and to the international judicial function

\footnotetext{
aggression and thereby making incidental determinations about the responsibility of a state under international law); Tzeng (n 12) 498-9.

155 As noted, the nature of the claims in Philippines $v$ China meant that the tribunal was able to do this, and this had been explicitly pleaded by the Philippines: Philippines v China (n 124) [153].

156 Mexico - Soft Drinks (n 99) [53]; L Bartels, 'Applicable Law in WTO Dispute Settlement Proceedings' (2001) 35 JWT 499. The provisions state that the DSB, panels and the Appellate Body 'cannot add to or diminish the rights and obligations provided in the covered agreements'.

157 See above at nn 114-15.

158 See above at n 115 .

${ }^{159}$ See, eg Bartels (n 102) 11-12; N Klein, 'The Effectiveness of the UNCLOS Dispute Settlement Regime: Reaching for the Stars?' (2014) ASIL Proc 359, 363.

160 Art 32 ECHR (' $[t]$ he jurisdiction of the Court shall extend to all matters concerning the interpretation and application of the Convention and the Protocols thereto').
} 
more generally. The apparent reluctance in the cases above of the ICJ, UNCLOS tribunals, and W'TO panels and Appellate Body to appear to be making determinations beyond their jurisdiction mirrors Cesare Romano's taxonomy of international courts and tribunals in which he groups these three sets of bodies together, noting that

... because of their state versus state nature, in these courts, diplomacy and sovereignty play important roles. These are the courts where the arbitral heritage and dispute settlement original rationale of international courts and tribunals is the most evident. They are, in a way, old-style courts, carrying in their structure and jurisdiction traits of the early days of the development of the current galaxy of international bodies. ${ }^{161}$

The ICJ, for example, though differing in important respects from its predecessors, does at the same time reflect a certain continuity with the Permanent Court of International Justice (and even the Permanent Court of Arbitration) in its identity as an organ for the settlement of bilateral interstate disputes, reflected most clearly in the retention of the requirement of consent to jurisdiction. ${ }^{162}$ This consensual basis of jurisdiction might help to explain the Court's 'restraint and caution' in certain cases ${ }^{163}$ including its approach in its provisional measures order in Ukraine v Russia in which it emphasised its limited jurisdiction and the self-contained nature of the claims. ${ }^{164}$ The Court, in this respect, is said to view itself as being in a transactional position in relation to the parties', ${ }^{165}$ and thus it exercises restraint not to go beyond the remit of its jurisdiction when addressing the specific inter-state dispute before it. Both the severability and restrictive approaches that were shown above to have been followed by the ICJ chime with this restrained view of the Court, as they both reflect (albeit to differing degrees) a limited approach to jurisdiction.

One can also see similar arguments being made with respect to the dispute settlement regimes under UNCLOS and the WTO. ${ }^{166}$ In the case of the WTO dispute settlement system, Joseph Weiler has argued that the diplomatic ethos of early GATT panels continues to influence the approaches of WTO panels and the Appellate Body. ${ }^{167}$ Indeed, Andrew Lang has invoked Weiler's thesis as a possible explanation for the WTO Appellate Body's restrained decision-making in certain areas, which might help to explain its reluctance in Mexico - Soft Drinks to appear to be stepping beyond the covered agreements:

${ }^{161}$ CPR Romano, 'A Taxonomy of International Rule of Law Institutions' (2011) 2 JIDS 241, 265. For a similar taxonomy, see RO Keohane, A Moravcsik, and A-M Slaughter, 'Legalized Dispute Resolution: Interstate and 'Transnational' (2000) 54 Intl Org 457.

162 GI Hernández, The International Court of Justice and the Judicial Function (OUP 2014) 40 ("[t]he Permanent Court transcended, at least partially, the substantially arbitral form of the Permanent Court of Arbitration, but retained a residual element of arbitral dispute-resolution in the consent required for it to take jurisdiction. The present International Court, with the same limitation on its jurisdiction, is no different'); M Bedjaoui, The New World Order and the Security Council: Testing the Legality of its Acts (Martinus Nijhoff 1994) 75 ('... conceptually, there has been no substantial evolution of the judicial function from one Court [PCIJ] to the other [ICJ]'); R Kolb, The Elgar Companion to the International Court of Justice (Edward Elgar 2014) 24-6.

${ }^{163}$ H Lauterpacht, The Development of International Law by the International Court (Stevens \& Sons 1958) 76 ('... a further reason for restraint and caution in the international sphere, namely, the fact of the voluntary nature of the jurisdiction of international tribunals'); Hernández, ibid, 50.

164 See above at text to $n 81$.

165 Hernández (n 162) 54 (using the non ultra petita principle as an example of how the Court occupies this transactional position); H Thirlway, 'The Drafting of ICJ Decisions: Some Personal Recollections and Observations' (2006) 5 Chinese J Intl L 15, 23-4; F Berman, 'The International Court of Justice as an 'Agent' of Legal Development' in CJ Tams and J Sloan (eds), The Development of International Law by the International Court of Justice (OUP 2013).

${ }^{166}$ With respect to UNCLOS, see N Klein, 'Expansions and Restrictions in the UNCLOS Dispute Settlement Regime: Lessons from Recent Decisions' (2016) 15 Chinese J Intl L 403, 415 (noting, as Sir Christopher Greenwood did in the context of the ICJ, the tension between effective resolution of maritime disputes and adherence to the principle of consent in UNCLOS dispute resolution).

${ }^{167} \mathrm{~J}$ Weiler, 'The Rule of Lawyers and the Ethos of Diplomats - Reflections on the Internal and External Legitimacy of WTO Dispute Settlement’ (2001) 35 JWT 191. 
... it does seem possible that the particular judicial style of the Appellate Body, its particular understanding of the judicial function and of the place of dispute settlement in the overall institutional structure, is a lawyerly expression of that diplomatic ethos carried out through judicial techniques. It is very different from the approach to fragmentation that we see in other institutions - think, for example, of the European Court of Justice, the European Court of Human Rights and the German Constitutional Court - in which the imagined role of the judicature is an altogether more "heroic" one, standing firmly on behalf of fundamental norms, defining the basic commitments of a political body or acting as the spokesperson for an imagined coherent legal order. ${ }^{168}$

Tribunals such as the ECtHR (particularly when addressing individual claims) do not fit so neatly into the 'dispute settlement' category - they are not in a 'transactional position in relation to the parties ${ }^{169}$ _ but reflect 'courts' in a more fundamental sense. They are said to represent the 'move from party-focused to legality-focused' tribunals, ${ }^{170}$ and from consensual to compulsory jurisdiction (in contrast to the ICJ, for example). ${ }^{171}$ In looking beyond bilateral inter-state disputes, and instead at (individual) human rights claims or individual criminal responsibility, bodies such as the ECtHR and ICC may place different weight on considerations such as consent when compared with the classic inter-state dispute settlement tribunals.

This, again, might go some way in explaining why the ECtHR, for example, not only does not generally claim that its rulings are without consequence for the broader inter-state disputes into which they sometimes fall, but occasionally explicitly makes legal determinations relevant to those broader disputes when ruling on the petition before it. ${ }^{172}$ Indeed, drawing a comparison to the often more restricted approach of the ICJ to its jurisdiction, Yuval Shany has noted that 'the legitimizing role of consent may be greater for some courts than for others' and that the move towards conferring compulsory jurisdiction on certain regime courts suggests that states 'place in some areas of their relations a lesser premium on consent ... [instead preferring] the greater degree of effectiveness in dispute resolution'. ${ }^{173}$ This is linked to the ECtHR's view of its own function, whereby it sees 'its mission under the ECHR as primarily directed at the promotion of respect for human rights' ${ }^{174}$

The argument should not, of course, be taken too far, or be seen as endorsing an essentialist account of international tribunals and their approaches to the jurisdictional issues discussed in this article. Tribunals do not follow a monolithic approach here. In suggesting that the ICJ's approach to these issues generally correlates with its historically inter-state dispute settlement function, I do not argue that the Court perceives itself as serving only this bilateral dispute settlement function, nor indeed that such a function can be performed without any broader consequence. ${ }^{175}$ It is also

\footnotetext{
168 A Lang, "Twenty Years of the WTO Appellate Body's "Fragmentation Jurisprudence"” (2015) 14 J Intl Trade Law \& Policy 116, 121. Similarly, see J Pauwelyn, 'The WTO 20 Years On: 'Global Governance by Judiciary' or, Rather, Member-driven Settlement of (Some) Trade Disputes between (Some) WTO Members?’ (2016) 27 EJIL 1119.

169 Hernández (n 162) 54.

170 Pauwelyn \& Salles (n 10) 84. Similarly, see Keohane, Moravcsik and Slaughter (n 161) 479-80 (noting that so-called 'transnational' dispute settlement bodies (such as the ECtHR) have much greater potential for legal evolution than socalled inter-state dispute settlement bodies (such as the ICJ or WTO)).

171 CPR Romano, 'The Shift from the Consensual to the Compulsory Paradigm in International Adjudication: Elements for a Theory of Consent' (2007) 39 NYU J Intl L \& Politics 791.

172 On the ECtHR's approach to jurisdiction generally, see A Mowbray, 'The Creativity of the European Court of Human Rights' (2005) 5 Hum Rts L Rev 57.

173 Y Shany, Questions of Jurisdiction and Admissibility before International Courts (CUP 2016) 43.

174 Ibid, 42.

175 See, eg, Lauterpacht (n 163) 3-7; C de Visscher, Théories et Réalités en Droit International Public (Pedone 1970) 390; A von Bogdandy and I Venzke, 'On the Functions of International Courts: An Appraisal in Light of their Burgeoning
} 
not to say that the principle of consent is always decisive for the ICJ when deciding issues of jurisdiction and admissibility. ${ }^{176}$ Similarly, if, in their reasoning, the Mauritius $v$ UK and Philippines v China tribunals endorsed a restrictive approach to these issues, in other respects UNCLOS tribunals have been more expansive in their approach to jurisdiction. ${ }^{177}$ With respect to the WTO Appellate Body, when viewed from other perspectives, its approach can also be seen as radical. ${ }^{178}$ Finally, the character of the Strasbourg Court too must not be over-simplified or caricatured as always endorsing an expansive interpretation of its own jurisdiction. ${ }^{179}$

The point here is not to flatten these nuances or to present a single explanation for the different approaches of each tribunal in any given case. Instead, the point is much more limited. It is simply that the different space within the architecture of international tribunals that organs such as the ICJ, UNCLOS tribunals, and Appellate Body occupy, in contrast to the ECtHR and ICC, might influence their approaches to the issues explored in this article. ${ }^{180}$ Which of the three approaches a tribunal adopts in any given case, therefore, may give some insight into how a particular tribunal understands its function. Importantly, as noted above, other considerations including the jurisdictional basis, the applicable law, and the substantive area of law will also all likely influence a particular tribunal's approach in a specific case.

These considerations regarding why one tribunal adopts the approach it does in a particular case might also help to inform our view of when each approach could be appropriate, whilst keeping in mind the caveat that any firm conclusion on this can only be made on a case-by-case basis. The severability approach, of course, offers a balance between enabling the tribunal to contribute to resolving the specific claim whilst remaining faithful to the principle of consent. It thus offers an attractive default option for any tribunal with a limited jurisdiction that is facing the types of jurisdiction or admissibility challenges discussed in this article.

The restrictive approach, though similarly reflective of the enduring role of consent in international dispute settlement, is more extreme, as the tribunal refuses even to rule on the issue

Public Authority' (2013) 26 Leiden J Intl L 49; CG Weeramantry, 'The Function of the International Court of Justice in the Development of International Law' (1997) 10 Leiden J Intl L 309; Hernández (n 162) 56.

176 See, eg, Certain German Interests in Polish Upper Silesia (n 84) 84 (the PCIJ applying, on one view, the expansive approach to the jurisdictional issues discussed here); Shany (n 173) 109-10 (suggesting one can see judicial activism by the ICJ in certain areas of high policy, such as use of force). And, as with other tribunals, if we broaden the analysis to include those cases in which the ICJ draws on extraneous primary rules ostensibly to interpret the principal norms that the Court has jurisdiction to apply, a much more expansive approach can be discerned: see above at $\mathrm{n} 84$.

177 See, eg, the line of cases relying on the applicable law clause in Article 293(1) UNCLOS as a basis for expanding the tribunals' jurisdiction beyond UNCLOS: The $M / V$ "Saiga" (No 2) Case (Saint Vincent and the Grenadines v Guinea), Judgment [1999] ITLOS Rep 10, Case No 2, [153]-[159]; Guyana v Suriname, PCA Case No 2004-04, Award, 17 September 2007, [402]-[406]; The M/V "Virginia G" Case (Panama/Guinea-Bissau), Judgment [2014] ITLOS Rep 4, Case No 19, [350]-[362]; for discussion, see P Tzeng, 'Jurisdiction and Applicable Law Under UNCLOS' (2016) 126 Yale LJ 242. See also Klein (n 166) 406-7, 412-13 (on the more expansive aspects of the Philippines v China award regarding its jurisdiction in other respects).

178 See, eg, DZ Cass, "The "Constitutionalization" of International Trade Law: Judicial Norm-Generation as the Engine of Constitutional Development in International Trade' (2001) 12 EJIL 39 (on the contribution of the Appellate Body to the development of constitutional norms in trade law); G Messenger, 'Claiming Judicial Authority at the W'TO: Submitting Diplomacy and Economics to Law' in G Hernández \& G Jokubauskaite (eds), Constructing Authority in International Law (OUP, forthcoming) (draft on file with author) (on the Appellate Body's construction of its own judicial authority and its dominance vis-à-vis the other WTO institutions); R Howse, 'The World Trade Organization 20 Years On: Global Governance by Judiciary' (2016) 27 EJIL 9 (on the Appellate Body's jurisprudential moves that transformed it into a judiciary independent of the other WTO institutions and their neo-liberal 'deep integration' philosophy).

${ }^{179}$ See, eg, Loizidou (n 147) [56] (the Court following the severability approach when noting that it did not need to rule on the legality or illegality of Turkey's military intervention). There is a rich and diverse literature on the nature of the ECtHR: see, eg, S Greer and L Wildhaber, 'Revisiting the Debate about 'constitutionalizing' the European Court of Human Rights' (2012) 12 Hum Rights L Rev 655; LR Helfer, 'Redesigning the European Court of Human Rights: Embeddedness as a Deep Structural Principle of the European Human Rights Regime' (2008) 19 EJIL 125.

180 See also Webb (n 10) 147-72 (noting different ways in which the identity of an international tribunal affects its approach to integration and fragmentation across international law). 
over which it seems to have jurisdiction where that would have implications for the broader dispute over which it does not. Where the nature of a particular tribunal is firmly rooted in the inter-state dispute settlement tradition, and particularly where there is no compulsory jurisdiction, adherence to the consent of the disputing states might be thought to carry special weight given its important legitimizing role. ${ }^{181}$ Given this, the restrictive approach might be thought the more appropriate option for such tribunals. However, since this approach involves a complete renunciation of any judicial role in settling the dispute before the tribunal, it should only exceptionally be followed. Indeed, as noted, the ICJ and UNCLOS cases adopting this approach all have either strong jurisdictional and/or substantive law justifications for doing so. ${ }^{182}$

Applying the restrictive approach beyond those specific contexts is problematic. The Philippines v China Tribunal's version of the restrictive approach, for example, is arguably too broad to be applied more generally by international tribunals, as it leaves no room for a tribunal to make a necessary incidental determination prior to ruling on the specific claims before it, no matter how minor is the incidental determination. ${ }^{183}$ Indeed, as the line between interpretation and application blurs, the Pbilippines $v$ China approach risks excluding an important source of legal reasoning. ${ }^{184}$ Furthermore, whilst the approach of the Mauritius $v$ UK tribunal was more balanced, recognising minor incidental sovereignty determinations to fall within the jurisdiction of UNCLOS tribunals, its focus on the character of the dispute ('the real issue in the case') is a challenge to the entire phenomenon of disaggregation of disputes. That is to say, rejecting a claim on the basis that it does not reflect the 'real' dispute fails to recognise that bringing highly specific legal claims as a means of litigating one part of a much broader (and perhaps quite different) dispute is a consequence of this structural feature of international judicial settlement. ${ }^{185}$

Finally, the expansive approach suggests much less of a preoccupation with consent than the other two approaches, and, again, the possible explanations for the ECtHR's use of this approach offer some guidance as to when it might be appropriate. Thus, the conferral by states on the ECtHR of compulsory jurisdiction, combined with its focus on claims that transcend the traditional inter-state dispute settlement model, suggest that its legitimacy is derived less from the continuing influence of consent and more from its function as a rule of law institution. This view of the Court is, of course, supported by its status as a human rights court, applying rules that it has at times explicitly held to be 'special' within the broader field of public international law. ${ }^{186}$ The same arguments would seem to apply, mutatis mutandis, to the ICC. It is clear, however, that the more traditional institutions, particularly the ICJ, for whom the continuing role of consent plays a significant legitimizing function, may face a greater challenge in justifying the expansive approach, ${ }^{187}$ though, again, other considerations may prove decisive.

\footnotetext{
181 See the quote from Shany above at text to $\mathrm{n} 173$.

182 See above at text to nn 155-8.

183 See above at text to $\mathrm{n} 140$.

${ }^{184}$ I refer here to those cases in which incidental determinations of law have been justified as necessary for interpreting the principal applicable norms: see, eg, those ICJ cases noted above at $\mathrm{n} 84$. Indeed, even the severability approach of the Appellate Body in Mexico - Soft Drinks has been criticised on this basis: Lang (n 100) 117; Bartels (n 102$) 19$.

${ }^{185}$ Hence the ICJ's general support for the severability approach: see above at text to nn 96-8. The criticisms of the Southern Bluefin Tuna Case focus on the Tribunal's failure to recognise this: see above at n 142.

186 Loizidou v Turkey, App No 15318/89, Judgment (Grand Chamber) (Preliminary Objections), 23 March 1995, [93] (on the severability of an invalid reservation from a contracting party's ratification of the Convention).

187 Again, the criticisms of the Court's Oil Platforms judgment illustrates this point well: see above at text to $\mathrm{n} 88$. It has been suggested that the difference between perceived legitimate and illegitimate incidental determinations might in part be one of form: Bartels ( $\mathrm{n}$ 102) 19 (on the Oil Platforms case, " $\mathrm{t}]$ he problem in that case was not the anterior determination. It was that the determination was arguably unnecessary, and also that the determination was included in the operative provisions of the judgment, even though it was on a topic that was not included in the substantive jurisdiction of the Court.')
} 


\section{CONCLUDING REMARKS}

This article has explored the phenomenon of what is termed the 'disaggregation of disputes', by which is meant the separation of broad inter-state disputes into discrete legal claims before different international tribunals, each with a specialised jurisdiction. In so doing, the article employs the ongoing Ukraine/Russia dispute as a case study in this phenomenon, considering the range of legal claims before different international courts and tribunals, the relationship between them, and the potential jurisdictional challenges that can arise as a result of this disaggregation. Importantly, as these cases are ongoing, the article draws on previous case law across a range of tribunals. In so doing, it reveals three broad approaches to these issues, offering an original analytical framework of relevance beyond the Ukraine/Russia litigation to international dispute settlement more generally. Which approach each tribunal seised in the Ukraine/Russia dispute might take remains to be seen.

The analysis reveals significant variance in how international tribunals engage with the phenomenon of disaggregation, both across different tribunals and across different cases before the same tribunal. It has been asked whether one might discern a general principle regarding how international tribunals address cases in which a broader dispute over which they do not have jurisdiction is implicated in the process of adjudicating the claims over which they do have jurisdiction. ${ }^{188}$ However, the variance revealed by the above analysis does not augur well for such a general principle. Indeed, as set out in section four, there are various case-specific considerations that might influence the approach of a tribunal to this issue in any given case. Furthermore, as argued in that section, the understanding of a particular tribunal to its function might also play some role here. Attempting to distil a general principle may not, therefore, be fruitful. ${ }^{189}$

It should finally be repeated that this article has not sought to engage with the normative debates surrounding the multiplication of international courts and tribunals. The fact that the structure of international dispute settlement can result in the disaggregation of disputes has been presented as both a blessing and a curse. For some, the opportunity that this provides for states to litigate and potentially resolve discrete legal aspects of long-term and intractable disputes is significant. ${ }^{190}$ For others, this disaggregation of disputes carries with it such negative externalities as forum-shopping, overlapping jurisdiction, and abuse of process. ${ }^{191}$ Indeed, Russia's arguments in these cases has extended to such objections. For example, in its preliminary objections to Ukraine's application to the ICJ, Russia argues that 'the claims brought before the ICJ and the ECtHR have the same essential basis: they rely on the same facts, they allege violations of the same basic rights and they seek equivalent remedies. ${ }^{192}$ Moreover, in its preliminary objections to Ukraine's 2016 UNCLOS claims, Russia argues that Ukraine's alleged shoehorning of the sovereignty dispute over Crimea into the Convention constitutes a 'misuse of the process' under Part XV UNCLOS. ${ }^{193}$ Whether any of the tribunals involved in the Ukraine/Russia cases would

\footnotetext{
188 See Tzeng (n 12).

189 Bartels (n 102) 11-12 ('[i]t may be thought that such questions involve the application of rules of 'international procedural law'. However, the better view might be that such rules are internal to the WTO').

${ }_{190}$ See, eg, Klein (n 159) 362 (in the context of UNCLOS dispute settlement); JH Jackson, World Trade and the Law of GATT (Bobbs-Merrill Company 1969) 767 (in the context of GATT dispute settlement).

191 On the risks and problems associated with forum-shopping, see, eg, Pauwelyn and Salles (n 10) 80-3.

192 Preliminary Objections (Russia) (n 20) [296]. A similar point has been raised by Russia in respect of Ukraine's request for interim relief before both the ECtHR and ITLOS following the November 2018 incident in the Kerch Strait: Case Concerning the Detention of Three Ukrainian Naval Vessels (Ukraine v The Russian Federation), Memorandum of Russia (n 25) [40].

${ }^{193}$ Dispute Concerning Coastal State Rights in the Black Sea, Sea of Azov, and Kerch Strait, Reply of the Russian Federation (n 120) [35]. The same argument was made by China in response to the Philippines' UNCLOS claims: Philippines v China (n 124) [124]-[129].
} 
accept such lis pendens or abuse of process-based arguments remains to be seen. ${ }^{194}$ Given that multiple, overlapping claims are a consequence of the disaggregated nature of international judicial settlement, such objections are likely to continue to arise in future cases.

${ }^{194}$ On the possibility of applying such concepts in international law, see Pauwelyn and Salles (n 10); Oellers-Frahm (n 10); C McLachlan, Lis Pendens in International Litigation (Brill 2009); AV Lowe, 'Overlapping Jurisdiction in International Tribunals' (1999) 20 Aust YB Intl L 191. 